\title{
PRIMJENA INPUT-OUTPUT MODELA U ANALIZI POTROŠNJE VODE KAO INPUTA U GOSPODARSTVU HRVATSKE
}

U radu se analizira primjena input-output modela u potrošnji vode gdje se istražuje povezanost vode kao ograničavajućeg resursa gospodarstva Hrvatske kroz međusektorske odnose proizvodnih sektora na koje je nacionalno gospodarstvo raščlanjeno, a temeljem dva hibridna input-output modela, za 2004. i 2010. godinu. Analizira se $i$ vremenska promjena povezanosti gospodarstva $i$ vodnih resursa. Budući da su proizvodni sektori međusobno povezani svaka promjena u agregatnoj potrošnji utjecat će na raspodjelu potrošnje vode na proizvodne sektore. Iz tog proizlazi važnost analize intermedijarnih odnosa na razini nacionalnog gospodarstva, a preko njih i utjecaj nacionalnog gospodarstva na raspoložive vodne resurse.

U radu se koristi hibridni input-output model potrošnje vode, rađen za 2004. i 2010. godinu, na temelju dostupnih publikacija Državnog zavoda za statistiku i Hrvatske agencije za okoliš i prirodu. Temeljne publikacije za izradu modela su tablice ponude $i$ uporabe, iz kojih su izvedene simetrične input-output tablice za 2004. i 2010. godinu te podaci o distribuciji vode za 2004. i 2010. godinu. Cjelokupno gospodarstvo Hrvatske u hibridnom modelu raščlanjeno na 22 proizvodna sektora. Pojedini proizvodni sektor nastao je objedinjavanjem različitih djelatnosti iz Nacionalne klasifikacije

${ }^{*}$ T. Gelo, dr. sc., izvanredni profesor, Sveučilište u Zagrebu, Ekonomski fakultet (e-mail:tgelo@ net.efzg.hr).

** D. Knez, univ. spec. oec., KNEZ INTEH d.o.o., (e- mail: dominik.knez@gmail.com). Rad je primljen u uredništvo 09.06.2020. godine, a prihvaćen je za objavu 01.02.2021. godine. Ovaj je rad financirala Hrvatska zaklada za znanost projektom (IP-2019-04-4500). 
djelatnosti (NKD) 2002. i 2007. Modelom se utvrđuju intenziteti direktne $i$ indirektne potrošnje vode, posljedično ukupna intenzivnost potrošnje vode te multiplikatori direktne i ukupne potrošnje. Rezultati modela za navedene godine ukazuju da u hrvatskom gospodarstvu svega nekoliko industrijskih sektora ima dominantan direktan utjecaj na vodne resurse (proizvodnja električne energije, koks i rafinirani naftni proizvodi te kemijski i farmaceutski proizvodi) te se preko njih voda distribuira u ostale gospodarske sektore. Smanjenje utjecaja na vodne resurse u Hrvatskoj može se postići smanjenjem intenzivnosti potrošnje vodnih resursa u promatranim sektorima. Pri primjeni dobivenih rezultata valja uzeti u obzir ograničenja hibridnog inputoutput modela koji je statičan te nedostatak podataka o potrošnji vode po svim sektorima.

Ključne riječi: hibridni model, input-output analiza, intenzivnost vode, sektori, gospodarstvo

\section{UVOD}

Voda je temelj života na zemlji. S obzirom na njenu važnost za život i čvrstu povezanost s društveno-ekonomskim razvojem čovječanstva, za svaku je državu važno posjedovati relevantne informacije koje će služiti kao podloga donositeljima politika o vodnim resursima. Podlogu za prikupljanje relevantnih informacija definirao je Statistički odjel Ujedinjenih naroda u dokumentu Sustav okolišnoekonomskih računa za vodu, koji predstavlja konceptualni okvir za koherentnu i konzistentnu organizaciju hidroloških i ekonomskih informacija. Upravo se integriranjem dostupnih ekonomskih, okolišnih, društvenih i drugih informacija predstavlja statistički okvir za praćenje interakcije između gospodarstva i vodnog okoliša te se stvara baza podataka za analiziranje određenih mjera te strateško planiranje koji su od vitalnog interesa za donositelje politika o održivom upravljanju vodnim resursima.

Dokument Sustav okolišno-ekonomskih računa za vodu potiče, između ostalog, i prikupljanje informacija o korištenju vodnih resursa kao inputa u gospodarskim aktivnostima pojedine države, čime se mogu identificirati dominantni izvori pritisaka na vodne resurse. Upravo je istraživanje brojnih ekonomista unazad nekoliko desetljeća usmjereno na analizu odnosa između ekonomije i okoliša, tj. između gospodarskih aktivnosti i dostupnih resursa iz prirode. U tom kontekstu, jedan od brojnih predmeta istraživanja svjetskih ekonomista je utvrditi koji gospodarski sektori, direktno i indirektno, troše najveće količine vodnih resursa. Odgovor na to pitanje može dati nekoliko metoda, od kojih je najcjelovitija input-output analiza, 
koja se temelji na Leontijevljevom input-output modelu koji se dodatno proširuje za informacije o vodnim resursima kao inputima, tvoreći hibridni input-output model. Hibridni input-output model potrošnje vode predstavlja koristan alat za analizu ključnih potrošača, uzimajući u obzir strukturu gospodarstva te daje opsežne informacije o vodnim tokovima iz okoliša prema gospodarstvu te unutar gospodarstva, iz čega proizlaze pokazatelji poput direktne, indirektne i ukupne intenzivnosti potrošnje vode i multiplikatora potrošnje vode. Važnost identifikacije ključnih potrošača vodnih resursa leži u činjenici da direktna sektorska potrošnja vodnih resursa nije relevantan podatak o sektorskoj potrošnji vode jer zanemaruje strukturu nacionalnog gospodarstva, stoga direktna sektorska potrošnja ne može biti adekvatna podloga donositeljima vodnih politika.

\section{PREGLED LITERATURE}

Unazad nekoliko desetljeća, ekonomisti istražuju i analiziraju međuovisnost između ekonomije i okoliša. Fokus takvih istraživanja bio je odnos između privrednih grana, potrošnje prirodnih resursa te onečišćenja koje nastaje uslijed privrednih aktivnosti. Ideje tadašnjih ekonomista pretočene su u ambiciozan dokument Sustav okolišno-ekonomskih računa (eng. System of Environmental and Economic Accounts, skraćeno: SEEA), razvijenog 1993. godine od strane Ujedinjenih naroda. U dokumentu predstavljeni su koncepti fizičkih i hibridnih, tj. monetarno-nemonetarnih računa kojima su povezane monetarne i nemonetarne veličine, čime se ekonomistima omogućilo konzistentno praćenje međuovisnosti fizičkih i monetarnih veličina. Poseban poticaj istraživanju odnosa između gospodarstva i okoliša donio je dokument Sustav okolišno-ekonomskih računa za vodu (eng. System of Environmental and Economic Accounts, skraćeno: SEEA-W), publiciran 2012. godine od strane Statističkog odjela Ujedinjenih naroda. Navedeni dokumenti dali su snažan poticaj za razvoj hibridnih input-output modela za potrošnju vode u zadnjih nekoliko desetljeća (Qin i ostali, 2013.). Najznačajnija istraživanja odnosa gospodarstva i vodnih resursa pomoću input-output modela za regionalna, nacionalna i nadnacionalna gospodarstva, prikazana su u Duarte et al. (2002), Velasquez (2006.), Hristov i ostali (2012.), Qin i ostali (2013.), Čegar (2016., 2020.), Boudhar i ostali (2017.). Hartman, (1965.) je utvrđivao je efikasnost regionalnog input-output modela u analizi potrošnje vode. Lenzen i Foran (2001.) su pomoću input-output metodologije analizirali multiplikativne učinke rasta stanovništva i potrošnje kućanstva na potrošnju vode u Australiji. Leistriz i ostali (2002.) istraživali su na području Sjeverne Dakote lokalni utjecaj ekonomije na upravljanje vodnim resursima. Duarte (at al., 2002) analizirala je potrošnju vode u španjolskom gospodarstvu i zaključila da se najviše vode troši u sektoru poljoprivrede, uslužnom 
sektoru, te kemijskoj i metalnoj industriji i elektronici. Velasquez (2006.) je istraživala međusektorske odnose u potrošnji vode u Andaluziji temeljem proširenog Leontijevljevog input-output modela u kombinaciji s Proopsovim modelom potrošnje energije. Zaključila je da sektor poljoprivrede ima veliku direktnu a malu indirektnu potrošnju dok je situacija u uslužnom (hoteli) i industrijskom sektoru (proizvodnja hrane) obrnuta, velika indirektna i mala direktna potrošnja. Okadera i ostali (2006.) su koristeći regionalni input-output model, određivali su potražnju za vodom i onečišćenje vode uslijed ekonomskih aktivnosti u gradu Chongqingu u Kini. Kobayashi i Oyasato (2008.) su pomoću proširene input-output analize određivali su ukupnu potrošnju vode u Japanu. Zaključili su da je indirektna potrošnja vode 2.6 puta veća od direktne potrošnje u cijelom japanskom gospodarstvu. Yu i ostali (2010.) su pomoću proširenog regionalnog input-output modela određivali su domaće i neto uvezene vodne otiske ekonomskih i kućanskih sektora u istočnoj Engleskoj. Njihovo istraživanje pokazalo je da najveću direktnu potrošnju ima sektor poljoprivrede a indirektnu potrošnju prehrambena industrija te uslužni sektor (trgovina, hoteli, restorani). Qin (2011.) je koristeći hibridni input-output model, utvrdio koji sektori direktno i indirektno najviše doprinose potrošnji vode i proizvodnji otpadnih voda u gospodarstvu slivnog područja rijeke Haihe u Kini. Hristov i ostali (2012.) su u svom su radu pomoću hibridnog input-output modela analizirali utjecaj međusektorskih odnosa na potrošnju vodnih resursa u Republici Makedoniji. Zaključak njihovog istraživanja je da su direktno vodno intenzivni sektor poljoprivrede a indirektno industrija naftnih derivata, rudarstvo i industrija metala. Bobylev, Yakovleva i Kudryavtseva (2013.) su direktnu i indirektnu potrebu za vodom po jedinici proizvoda u Rusiji pomoću proširene input-output analize. Najveću direktnu potrošnju ima sektor proizvodnje električne energije te drvna i papirna industrija dok u indirektnoj potrošnji prednjače kemijska industrija, drvna i papirna industrija te industrija hrane. Deng i ostali (2014.) su analizirali proširenu input-output tablicu napravljenu za analizu potražnje i potrošnje vode na lokalnoj razini u Kini. Industrijalizacija Kine i povećanje potrošnje kućanstava utječe na ubrzanje gospodarskog rasta, ali uz visoku cijenu potrošnje vode kroz sekundarni i tercijarni sektor. Boudhar i ostali (2017.) su pomoću hibridnog input-output modela analizirali su odnos između gospodarskih sektora, potrošnje vode te međusektorsku potrošnju vode u Maroku. Zaključili su da najveću direktnu potrošnju vode ima sektor poljoprivrede a indirektnu industrija hrane i duhanskih proizvoda te hoteli i restorani u uslužnom sektoru.

U Hrvatskoj je Čegar (2016., 2020.) u doktorskoj disertaciji na temelju proširenog input-output modela temeljenog na 24 proizvodna sektora za 2010. godinu, utvrdio je da su proizvodnja električne energije, kemijska industrija i industrija naftnih proizvoda imaju najveći kumulativan utjecaj na nacionalne vodne resurse u hrvatskom gospodarstvu. 


\section{HIBRIDNI INPUT-OUTPUT MODEL POTROŠNJE VODE}

U provođenju politike voda koja će zadovoljavati koncepte integriranog upravljanja vodnim resursima, važno je prepoznati odnose između gospodarstva i vodnih resursa. Hibridne, vodno-ekonomske analize zahtijevaju konzistentan pristup u prikupljanju i obradi relevantnih podataka o gospodarstvu i vodnim resursima, stoga je UN razvio koncept Sustav okolišno-ekonomskih računa za vodu, u kojima se kao metoda analize odnosa ekonomije i vodnih resursa predstavlja hibridni input-output model. Hibridnim input-output modelom istražuju se odnosi između potrošnje vode i gospodarskih sektora, analizira se međusektorska potrošnja vode te se temeljem modela mogu utvrditi utjecaji promjene finalne potrošnje pojedinih sektora na ukupnu potrošnju vodnih resursa (Boudhar i ostali, 2017.). Hibridna input-output analiza predstavlja top-down ekonomsku metodu u kojoj se pomoću sektorskih monetarnih transakcija kvantificiraju sektorske međuovisnosti (Qin i ostali, 2013.)

\subsection{Proširena input-output tablica $i$ struktura hibridnog modela}

Hibridni input-output model za potrošnju vode razvijen je na temelju osnovnog input-output modela. Prema input-output analizi, u proizvodnji pojedinog sektora, kao inputi koriste se outputi drugih proizvodnih sektora te nam upravo input-output analiza daje mogućnost utvrđivanja međusektorskih odnosa (Qin i ostali., 2013.). Zbroj direktne i indirektne potrošnje vode sektora i jednak je ukupnoj potrošnji vode sektora i (Boudhar i ostali, 2017.).

Proširena input-output tablica pokazuje monetarne i nemonetarne tokove te povezuje tokove proizvodnje roba i usluga te količine vode koju proizvodni sektori nekog gospodarstva utroše. Količine vode koje pojedini sektor potroši pri proizvodnji svojih outputa prikazani su kao primarni inputi, tj. količine vode imaju egzogena obilježja, jer vodni resursi nisu proizvedeni ni u jednom od sektora na koje je gospodarstvo raščlanjeno. U hibridnom input-output modelu, kao prva konekcija između monetarnih i nemonetarnih veličina definirana je intenzivnost direktne potrošnje vode, koji se definira kao omjer godišnje količine vode koju direktno potroši sektor j i ukupnog inputa tog sektora (npr. Velasquez, 2006.):

$$
d_{j}=\frac{w_{j}}{X_{j}}, \mathrm{j}=1,2, \ldots, \mathrm{n}
$$


Intenzitet direktne potrošnje vode odražava direktnu potrošnju vode od strane sektora j u odnosu na ukupni monetarni input tog sektora, a iskazuje se u mjernoj jedinici $\mathrm{m}^{3} / \mathrm{mil}$. HRK ili neke druge valute. Kako je u input-output analizi ukupni input pojedinog sektora jednak ukupnom outputu, tada se intenzivnost direktne potrošnje vode može promatrati kao omjer količine vode koju pojedini sektor direktno potroši pri proizvodnji jedne jedinice outputa tog istog sektora. U hibridnom input-output modelu, intenziteti direktne potrošnje vode zapisuju se u obliku dijagonalne matrice reda $\mathrm{n}$, gdje je $\mathrm{n}$ broj sektora na koje je pojedino gospodarstvo raščlanjeno. Elementi dijagonalne matrice intenziteta direktne potrošnje jednaki su definiranim intenzitetima direktne potrošnje vode za svaki sektor, dok su ostali elementi matrice jednaki nuli. Navedena matrica intenziteta direktne potrošnje vode zapisuje se kao (npr. Čegar, 2016.):

$$
\hat{d}_{k}=\left[\begin{array}{ccccc}
d_{k 1} & \cdots & 0 & \cdots & 0 \\
\vdots & \ddots & \vdots & & \vdots \\
0 & \cdots & d_{k j} & \cdots & 0 \\
\vdots & & \vdots & \ddots & \vdots \\
0 & \cdots & 0 & \cdots & d_{k n}
\end{array}\right], \quad k=1,2 . \quad\left[\begin{array}{ccccc}
d_{1} & \cdots & 0 & \cdots & 0 \\
\vdots & \ddots & \vdots & & \vdots \\
0 & \cdots & d_{j} & \cdots & 0 \\
\vdots & & \vdots & \ddots & \vdots \\
0 & \cdots & 0 & \cdots & d_{n}
\end{array}\right], d_{j}=\frac{W_{j}}{X_{j}}
$$

Pojedini sektor u gospodarstvu troši određenu razinu resursa i indirektno, koristeći outpute drugih sektora kao svoje inpute pri proizvodnji svojih outputa. Samim time, određeni sektor j u gospodarstvu indirektno troši i određene indirektne količine vode. Iz tog razloga važno je vratiti se na definiciju inverzne Leontijevljeve matrice, koja kaže da je inverzna Leontijevljeva matrica kvadratna matrica reda n čiji su elementi nazvani sektorski multiplikatori, a pokazuju veličinu proizvodnje sektora i koja je direktno i indirektno uvjetovana svakom jedinicom finalne potrošnje sektora j (Velasquez 2006.). Množenjem matrice koeficijenata direktne potrošnje vode D i inverzne Leontijevljeve matrice (ILM) moguće je za svaki od n sektora odrediti koliko cjelokupno gospodarstvo mora potrošiti vode da bi se proizvela jedna jedinica outputa promatranog sektora. To zapisujemo na sljedeći način (Qin, i ostali. 2013., Čegar, 2016.), pomoću matrice ukupne intenzivnosti potrošnje vode:

$$
\mathrm{T}=\mathrm{D} \cdot \mathrm{ILM} \text {, gdje je ILM }=(\mathrm{I}-\mathrm{A})^{-1} .
$$


Interpretacija matrice ukupne intenzivnosti potrošnje vode $\mathrm{T}$ moguća je preko retka i stupca, gdje suma elemenata u stupcu j označava količinu vode koju gospodarstvo dodatno troši, direktno i indirektno, kako bi se proizveli svi inputi koji su potrebni sektoru j pri proizvodnji jedne jedinice outputa tog sektora. Suma elemenata u retku i predstavlja ukupnu količinu vode koju sektor i dodatno, direktno i indirektno, troši kako bi proizveo one inpute, koji su direktno i indirektno potrebni ostalim sektorima, uključujući sektoru i pri proizvodnji jediničnog outputa (Velasquez, 2006.).

Prema Hristov i ostali (2012.), nakon definicije matrice T, moguće je definirati matricu intermedijarnih tokova vode, po uzoru na određivanje sume serije indirektnih efekata u jednadžbi. Matrica intermedijarnih tokova $\mathrm{W}$ reda $\mathrm{n}$ dobiva se na način da se od matrice $T$ oduzme matrica direktne potrošnje vode $D, t j$.:

$$
\mathrm{W}=\mathrm{T}-\mathrm{D}=\mathrm{D} \cdot(\mathrm{I}-\mathrm{A})^{-1}-\mathrm{D}=\mathrm{D}\left[(\mathrm{I}-\mathrm{A})^{-1}-1\right],
$$

gdje pojedini elementi matrice intermedijarnih tokova, $\mathrm{w}_{\mathrm{ij}}{ }^{\mathrm{int}}$ označavaju ukupne količine vode koje će sektor i dodatno potrošiti kako bi proizveo dovoljno inputa koje sektor $\mathrm{j}$ koristi za jedinicu svog outputa. Iz tog slijedi da suma elemenata $\mathrm{u}$ stupcu j matrice $\mathrm{W}^{\text {int }}$ zapravo ukupna indirektna potrošnja sektora $\mathrm{j}$ na razini jedinične proizvodnje. Suma elemenata j-tog stupca matrice $\mathrm{W}^{\text {int }}$ označava intenzivnost indirektne potrošnje vode sektora $\mathrm{j}$, tj. količinu vode koju sektor $\mathrm{j}$ indirektno potroši pri proizvodnji jediničnog outputa. Suma intenzivnosti direktne potrošnje vode i intenzivnosti indirektne potrošnje vode definirana je kao ukupna intenzivnost potrošnje vode, a označava koliko pojedini sektor, direktno i indirektno, troši vode pri proizvodnji jediničnog outputa. Također se prema Hristov i ostali (2012.), dobivena matrica, s obzirom da prikazuje strukturu intermedijarnih tokova vode u nacionalnom gospodarstvu, može konvertirati u matricu tehničkih koeficijenata vode AW, gdje je element matrice AW, tehnički koeficijent vode $\mathrm{aw}_{\mathrm{ij}}$, definiran kao omjer između elementa matrice intermedijarnih tokova i matrice direktnih tokova:

$$
a w_{i j}=\frac{w_{i j}^{\text {int }}}{d_{j}} ; i, j=1, \ldots, n .
$$

gdje, $a_{\mathrm{ij}}$ označava količinu dodatne potrošnje vode u sektoru i uslijed jediničnog povećanja direktne potrošnje vode u sektoru j. Samim time, suma stupca j u matrici AW označava povećanje indirektne potrošnje vode u sektoru j uslijed jediničnog direktnog povećanja potrošnje vode tog istog sektora $j$.

Može se odrediti i povećanje ukupne, direktne i indirektne potrošnje vode u sektoru j uslijed jediničnog direktnog povećanja potrošnje vode sektora j. Naime 
jednadžbu je bilo potrebno modificirati pri određivanju indirektnih efekata jedinice finalnih isporuka sektora i na razinu proizvodnje sektora i, budući da sektor i mora, da bi proizveo i isporučio svoj finalni proizvod, osim finalnog proizvoda proizvesti i reprodukcijski materijal za vlastitu potrošnju u veličini određenoj tehnički koeficijentom $a_{\text {ii. }}$ Pri povećanju direktne potrošnje vode za jednu jedinicu, mora povećati i količina vode koja se koristi kao reprodukcijski materijal sektora j, što znači da je ukupna direktna i indirektna potrošnja vode sektora j uslijed jediničnog povećanja direktne potrošnje vode veća za 1 od indirektnog povećanja vode u sektoru j uslijed jediničnog direktnog povećanja potrošnje sektora j.

Prema Qin (2013.) se interpretira uvođenjem dviju novih veličina: multiplikatora ukupne potrošnje te multiplikatora indirektne potrošnje. Za mjerenje intenzivnosti utjecaja jedinične promjene outputa pojedinog sektora na cjelokupno gospodarstvo, definiraju se ukupni i indirektni multiplikatori potrošnje pojedinog sektora $\mathrm{m}^{\mathrm{uk}} \mathrm{i} \mathrm{m}^{\text {ind }}$, gdje je $\mathrm{m}^{\mathrm{uk}}$ multiplikator ukupne potrošnje, a $\mathrm{m}^{\text {ind }}$ indirektne potrošnje. Oni se računaju na sljedeći način:

$$
\begin{aligned}
& m_{j}^{u k}=\frac{t_{j}}{d_{j}}, \\
& m_{j}^{i n d}=\frac{t_{j}-d_{j}}{d_{j}}=m_{j}^{u k}-1,
\end{aligned}
$$

gdje je $t_{j}$ element matrice ukupne intenzivnosti potrošnje vode $T$, dok je $d_{j}$ element matrice direktne potrošnje vode. Multiplikator ukupne potrošnje pokazuje za koliko će se povećati ukupna, direktna i indirektna, potrošnja vode sektora j ako dođe do jediničnog povećanja outputa sektora j, odnosno, koliko će se povećati potrošnja vode sektora $\mathrm{j}$ ako dođe do jediničnog $\left(1 \mathrm{~m}^{3}\right)$ povećanja direktne potrošnje sektora j. Nasuprot njemu, multiplikator indirektne potrošnje, kao omjer između indirektnog i direktnog efekta jedinične promjene outputa sektora j na vodne resurse, pokazuje za koliko se povećava indirektna potrošnja vode sektora j u odnosu na jedinično povećanje direktne potrošnje vode sektora j, kako bi se zadovoljila ukupna potrošnja tog sektora (Velasquez, 2006.). Iz toga proizlazi da je zbroj elemenata u sektoru j matrice tehničkih koeficijenata vode AW jednak vrijednosti multiplikatora indirektne potrošnje vode koji je definiran jednadžbom (7). 


\subsection{Korišteni podaci}

Prema hibridnom input-output modelu potrebno je povezivanje monetarnih i nemonetarnih podataka, publiciranih od strane Državnog zavoda za statistiku te Hrvatske agencije za okoliš i prirodu. DZS je objavio simetrične input-output tablice za 2004. i 2010. godinu te podatke o korištenju i distribuciji vode u industriji u 2004. i 2010. godini. Hrvatska agencija za okoliš i prirodu objavila je Izvješća o stanju okoliša za višegodišnja razdoblja, iz čega su procijenjene količine vode koje su direktno trošene za navodnjavanje i ostale namjene u primarnom sektoru. S obzirom na dostupnost podataka o količinama utrošene vode po sektorima, koji su se u značajnoj mjeri morali obraditi i aproksimirati, u modelu je korištena veća razina agregacije proizvodnih sektora, iz čega je proizašao broj sektora u modelu 22 , što je utjecalo na detaljnost rezultata modela. U tablici $1 \mathrm{u}$ Prilogu prikazano je disageragcija hrvatskog gospodarstva na 22 sektora. DZS (2005.) u publikaciji Korištenje voda i zaštita voda od zagađivanja u industriji u 2004. objavio je podatke o Korištenju vode prema namjeni prema NKD-u 2002. u 2004. godini. DZS (2005.) je objavio je publikaciju Skupljanje, pročišćavanje i distribucija vode u 2004. godini, gdje je objavljen podatak o isporučenoj vodi gospodarstvu iz javnog vodovoda, što je, uzimajući u obzir pretpostavku da Uslužne djelatnosti svoje potrebe za vodom ostvaruju iz javnog vodovoda, osnova za količinu direktne potrošnje koju sektor Uslužne djelatnosti ostvaruje. Direktna količina vode koju troši Primarni sektor temeljena je na Izvješću o stanju okoliša u Hrvatskoj za razdoblje 2005. - 2008. (2012.). Kako u Primarni sektor ulazi i djelatnost Uzgoj riba, za čije se potrebe korištena voda može koristiti i u drugim djelatnostima, kao direktne utrošene količine u Primarnom sektoru uzete su količine vode za navodnjavanje, korištenje termalnih i mineralnih voda te korištenje vode za ostale namjene. Kako se tehnologija navodnjavanja unaprijedila tek nakon razdoblja (Hrvatska agencija za okoliš i prirodu, 2012.) za koje je spomenuto Izvješce publicirano, te se time smanjile količine vode utrošene na navodnjavanje, za potrebe modela korišten je navedeni podatak o prosječnoj količini vode korištene za navodnjavanje iz spomenute publikacije. DZS (2011.) u publikaciji Korištenje voda i zaštita voda od zagađivanja u industriji u 2010. objavio je podatke o Korištenju vode prema namjeni prema NKD-u 2007. u 2010. godini. DZS (2011.) objavio je publikaciju Skupljanje, pročišćavanje i distribucija vode u 2010. godini, temeljem kojih su određene količine utrošene vode u sektoru Uslužne djelatnosti. U dokumentu Izvješće o stanju okoliša u Hrvatskoj, 2014. (razdoblje od 2009. do 2012.) (2015.), procijenjene su godišnje količine vode koje su se u navedenom razdoblju koristile za navodnjavanje i ostale namjene. 
T. GELO, D. KNEZ: Primjena input-output modela u analizi potrošnje vode kao inputa u gospodarstvu Hrvatske EKONOMSKI PREGLED, 72 (2) 272-307 (2021)

\section{REZULTATI}

\subsection{Analiza rezultata za 2004. godinu}

Količina direktne neto potrošnje vode za potrebe hrvatskog gospodarstva, u 2004. godini iznosila je $524.961 .000 \mathrm{~m}^{3}$ vode. S obzirom na klasifikaciju sektora, prema Boudhar (2017.), najveći direktni potrošač vode je sekundarni sektor, čija je direktna neto potrošnja iznosila $452.611 .000 \mathrm{~m}^{3}$. Slijede tercijarni, kvartarni i kvintarni sektor, koji su agregirani u jedan modelski sektor, Uslužne djelatnosti, s količinom od $65.150 .000 \mathrm{~m}^{3}$, dok je primarni sektor 2004. godine direktno utrošio $7.200 .000 \mathrm{~m}^{3}$ vode. Analiza direktne i indirektne intenzivnosti potrošnje vodnih resursa pokazuje da sektori iz modela koji se ubrajaju u sekundarni sektor imaju najveće vrijednosti direktne i indirektne intenzivnosti, tj. najveće vrijednosti ukupne intenzivnosti potrošnje vodnih resursa. Kako je za sektore Proizvodnja koksa i rafiniranih naftnih proizvoda, Proizvodnja kemijskih i farmaceutskih proizvoda te Opskrba električnom energijom, plinom, parom i klimatizacija karakteristično to da, osim što imaju najveće vrijednosti direktne potrošnje vode, imaju i značajan udio u indirektnoj potrošnji ostalih sektora, razvidno je kako su upravo ti sektori glavni potrošački sektori vode u Hrvatskoj u 2004. godini. Preko proizvodnje proizvoda i usluga navedenih sektora voda se dominantno distribuira po ostalim sektorima.

\subsubsection{Direktna neto potrošnja i direktna intenzivnost potrošnje vode u 2004. godini}

U 2004. godini sektor Opskrba električnom energijom, plinom, parom i klimatizacija direktno je utrošio $143.219 .000 \mathrm{~m}^{3}$ vode, što je činilo 27,3\% ukupno utrošene količine. S udjelom od 23,6\%, drugi, najveći direktni potrošač vode bio je sektor Proizvodnja koksa i rafiniranih naftnih proizvoda, gdje je utrošeno $123.714 .591 \mathrm{~m}^{3}$ vode. Treći najveći direktni potrošač vode jest sektor Proizvodnja kemijskih i farmaceutskih proizvoda, s količinama od $119.361 .000 \mathrm{~m}^{3}$, što čini 22,7\% ukupne potrošnje. Uzrok male potrošnje vode u Primarnom sektoru leži u nepostojanju velikih sustava za navodnjavanje te napretku u tehnologiji navodnjavanja. Vrijednosti direktne neto potrošnje za svaki sektor nalaze se u tablici $2 \mathrm{u}$ Prilogu.

Izračunata je i intenzivnost direktne potrošnje koja se izražava kao omjer količine direktno utrošene vode i vrijednosti, u milijunima kuna, ostvarenog outputa. 
Najveće količine vode po milijun kuna outputa utrošeno je u sektoru Proizvodnja koksa i rafiniranih naftnih proizvoda, u vrijednosti od $9.637 \mathrm{~m}^{3} /$ milijun HRK. Slijedi ga sektor Opskrba električnom energijom, plinom, parom i klimatizacija s vrijednošću od $7.489 \mathrm{~m}^{3}$ / milijun HRK te Proizvodnja kemijskih i farmaceutskih proizvoda, u kojem se za milijun HRK outputa direktno utroši $6.209 \mathrm{~m}^{3}$. Iako je po apsolutnim količinama sektor Uslužne djelatnosti četvrti najveći potrošač u 2004., po intenzivnosti direktne potrošnje vode taj je sektor ispodprosječan, s utrošenom količinom vode od $261 \mathrm{~m}^{3}$ po milijun kuna outputa. Sektor s četvrtom najvećom direktnom intenzivnosti potrošnje vode jest Distribucija vode i gospodarenje otpadom s $2.375 \mathrm{~m}^{3} /$ milijun HRK, iako je udio tog sektora u ukupnoj direktnoj neto potrošnji svega $1,4 \%$. Sektor Proizvodnja prehrambenih i duhanskih proizvoda troši iznadprosječne direktne količine vode u količini od $31.009 .000 \mathrm{~m}^{3}$, dok je zbog relativno visokog ostvarenog outputa intenzivnost direktne potrošnje tog sektora ispodprosječna, u iznosu od $922 \mathrm{~m}^{3}$ vode po milijun kuna outputa. Istovremeno sektor Distribucija vode i gospodarenje otpadom troši ispodprosječne direktne količine vode u količini od $7.102 .000 \mathrm{~m}^{3}$, dok je zbog relativno niskog ostvarenog outputa intenzivnost direktne potrošnje tog sektora iznadprosječna, u iznosu od $2.375 \mathrm{~m}^{3}$ vode po milijun kuna outputa. Na grafikonu 1 prikazani su odnosi direktne neto potrošnje i intenzivnosti direktne potrošnje vode po sektorima u 2004. godini.

\section{Grafikon 1:}

\section{DIREKTNA NETO POTROŠNJA I INTENZIVNOST POTROŠNJE PO SEKTORIMA U 2004. GODINI}

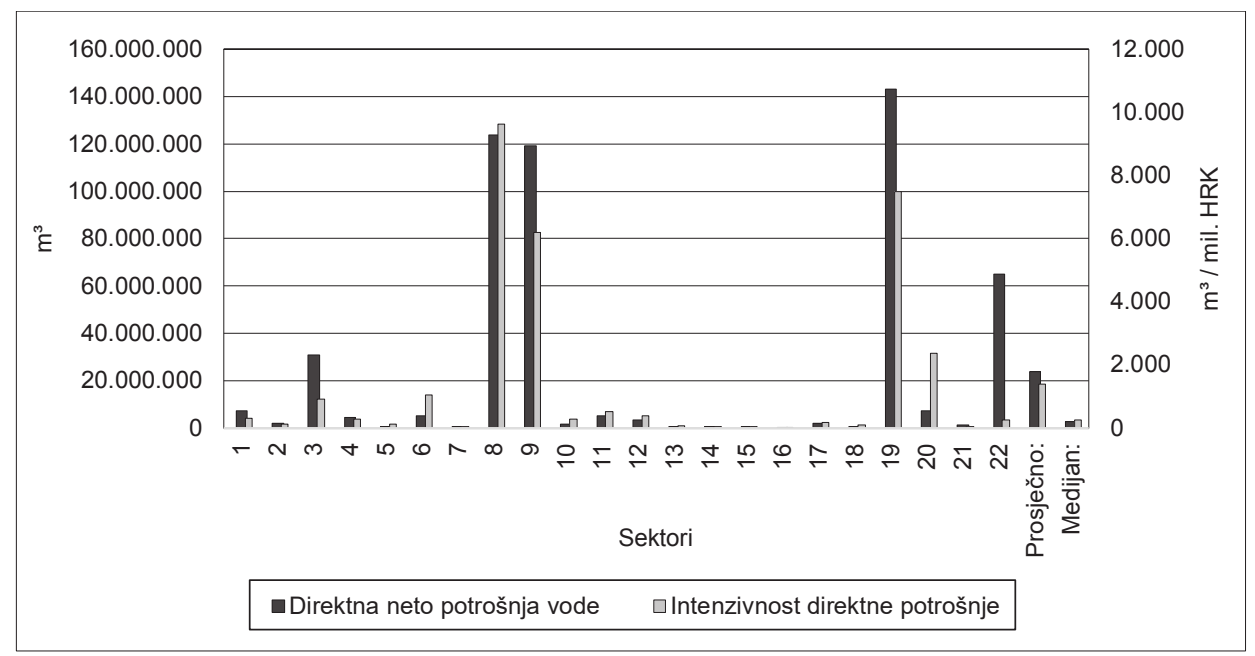

Izvor: izračun autora 


\subsubsection{Međusektorski vodni tokovi i ukupna intenzivnost potrošnje vode u 2004. godini}

Analizom isključivo intenzivnosti direktne potrošnje, zanemaruju se međusektorski odnosi i stvarni utjecaj pojedinih gospodarskih sektora na vodne resurse. Iz analize intenzivnosti indirektne potrošnje vode vidljivo je da sektori poput Tiskanje i srodne usluge, Proizvodnja proizvoda od gume i plastike, Građevinarstvo i Proizvodnja ostalih nemetalnih proizvoda, iako troše ispodprosječne direktno neto količine vode, po intenzivnosti indirektne potrošnje vode ubrajaju se u sektore s iznadprosječnom intenzivnosti. U tablici 3 u Prilogu prikazane su vrijednosti intenzivnosti indirektne potrošnje vode te ukupne intenzivnosti potrošnje vode po sektorima. Sektor Opskrba električnom energijom, plinom, parom i klimatizacija ima najveću intenzivnost indirektne potrošnje vode u iznosu od $2.788 \mathrm{~m}^{3}$ po milijun kuna outputa. Slijede sektori Distribucija vode i gospodarenje otpadom, s iznosom intenzivnosti indirektne potrošnje od $1.725 \mathrm{~m}^{3}$ po milijun kuna outputa, Proizvodnja ostalih nemetalnih mineralnih proizvoda s iznosom od $1.643 \mathrm{~m}^{3}$ po milijun kuna outputa te Proizvodnja kemijskih i farmaceutskih proizvoda s indirektnom potrošnjom od $1.584 \mathrm{~m}^{3}$ po milijun kuna outputa. Kako bi se kvantificirale intenzivnosti indirektne potrošnje pojedinih sektora, promatraju se međusektorski vodni tokovi. U tablici 4 u Prilogu prikazani su međusektorski vodni tokovi za pojedine sektore u 2004. godini. Razmatrajući strukturu indirektne intenzivnosti, tj. intermedijarnih tokova svakog sektora pomoću matrice intermedijarnih tokova, za navedene se sektore, koje obilježava najveća intenzivnost indirektne potrošnje, može izvesti zajednički zaključak da se njihova indirektna potrošnja dominantno odnosi na sektore Proizvodnja koksa i rafiniranih naftnih proizvoda, Proizvodnja kemijskih i farmaceutskih proizvoda te Opskrba električnom energijom, plinom, parom i klimatizacija. Kako suma retka matrice intermedijarnih tokova W (Tablica 4 u Prilogu) označava intenzivnost indirektne potrošnje pojedinog sektora pri proizvodnji intermedijarnih inputa za jedinični output svakog sektora, zaključuje se da sektor Opskrba električnom energijom, plinom, parom i klimatizacija za milijun kuna outputa svih sektora utroši najviše, tj. $9.076 \mathrm{~m}^{3}$ vode, dok slijede sektori Proizvodnja kemijskih i farmaceutskih proizvoda s potrošnjom od $5.557 \mathrm{~m}^{3}$ te Proizvodnja koksa i rafiniranih naftnih proizvoda s potrošnjom od $2.882 \mathrm{~m}^{3}$ po milijun kuna outputa svakog sektora. Sektor Uslužne djelatnosti indirektno utroše $1.238 \mathrm{~m}^{3}$ vode po milijun kuna outputa svih sektora, dok ostali sektori troše manje od $500 \mathrm{~m}^{3}$ vode po milijun kuna, što ukazuje na činjenicu da je utjecaj ostalih sektora na potrošnju vode, uzrokovanu proizvodnjom intermedijarnih inputa, značajno manja od utjecaja sektora Opskrba električnom energijom, plinom, parom i klimatizacijom, Proizvodnja kemijskih i farmaceutskih proizvoda te Proizvodnja koksa i rafiniranih naftnih proizvoda na potrošnju vode uslijed proizvodnje intermedijarnih inputa. Uzevši u obzir direktnu 
i indirektnu intenzivnost potrošnje, pomoću ukupne intenzivnosti potrošnje vode za svaki se sektor može utvrditi veličina ukupnog utjecaja na vodne resurse. Ono što se uočava jest da oni sektori, koji imaju najveću direktnu intenzivnost potrošnje, imaju i najveću ukupnu intenzivnost potrošnje vode. Sektor Opskrba električnom energijom, plinom, parom i klimatizacija bilježi vrijednost ukupne intenzivnosti od $10.277 \mathrm{~m}^{3}$ / mil. HRK, sektor Proizvodnja koksa i rafiniranih naftnih proizvoda bilježi vrijednost ukupne intenzivnosti od $10.183 \mathrm{~m}^{3}$ / mil. HRK, Proizvodnja kemijskih i farmaceutskih proizvoda vrijednost od $7.792 \mathrm{~m}^{3} /$ mil. HRK te Distribucija vode i gospodarenje otpadom $4.100 \mathrm{~m}^{3} / \mathrm{mil}$. HRK.

\subsubsection{Analiza multiplikatora ukupne i indirektne potrošnje u 2004.}

Multiplikatorima ukupne i indirektne intenzivnosti potrošnje identificiraju se oni sektori koji potencijalno mogu najviše multiplicirati potrošnju vode u čitavom gospodarstvu. U tablici 5 u Prilogu prikazane su vrijednosti multiplikatora za svaki sektor. Sektori koji imaju dominantnu indirektnu intenzivnost potrošnje vode u odnosu na direktnu intenzivnosti, bilježe i najveće vrijednosti ukupnog i indirektnog multiplikatora potrošnje. Sektor Građevinarstvo, koji ima udio indirektne potrošnje od $97 \%$ u odnosu na ukupnu potrošnju, ima vrijednost multiplikatora ukupne potrošnje 38 , a indirektne potrošnje 37 . U tom se sektoru za svaki $1 \mathrm{~m}^{3}$ povećanja direktne potrošene vode, indirektno potroši $37 \mathrm{~m}^{3}$ vode. Sektor Tiskanje i usluge, koji ima udio indirektne potrošnje od $96 \%$ u odnosu na ukupnu potrošnju, bilježi drugu najveću vrijednost multiplikatora ukupne i indirektne potrošnje, u iznosu od 26 za ukupnu te 25 za indirektnu potrošnju. Iako sektor Opskrba električnom energijom, plinom, parom i klimatizacija ima najveću vrijednost intenzivnosti indirektne potrošnje vode u iznosu od $2.788 \mathrm{~m}^{3} / \mathrm{mil}$. HRK, zbog dominantnog udjela intenzivnosti direktne potrošnje vode taj sektor bilježi vrijednost indirektnog multiplikatora 0,4 . To ukazuje da taj sektor, relativno gledano nema potencijal multiplikacije potrošnje vode u ostalim sektorima. U tablici $6 \mathrm{u}$ Prilogu prikazana je raspodjela multiplikatora indirektne potrošnje pojedinog sektora na sve sektore na koje je gospodarstvo Hrvatske raščlanjeno. Za, primjerice, 1 $\mathrm{m}^{3}$ direktnog povećanja potrošnje vode u sektoru Tiskanje i srodne usluge, sektor Proizvodnja kemijskih i farmaceutskih proizvoda mora, za proizvodnju intermedijarnih inputa, dodatno potrošiti $11,157 \mathrm{~m}^{3}$ vode, a sektor Opskrbe električnom energijom, plinom, parom i klimatizacija $6,567 \mathrm{~m}^{3}$ vode. Kako suma retka matrice tehničkih koeficijenata vode AW (Prilog 4) označava indirektne multiplikatore potrošnje vode pojedinog sektora pri jediničnom povećanju direktne potrošnje svakog sektora, uočava se da sektori Opskrba električnom energijom, plinom, parom i klimatizacija, Proizvodnja kemijskih i farmaceutskih proizvoda te Proizvodnja 
koksa i rafiniranih proizvoda bilježe najveće vrijednosti indirektnog multiplikatora u iznosima od 59,6, 40,5 te 21,2. Ako se u svim sektora jedinično poveća direktna potrošnja vode, tj. za $1 \mathrm{~m}^{3}$, to će uzrokovati multiplikaciju potrošnje vode u sektoru Opskrba električnom energijom, plinom, parom i klimatizacijom od 59,6 $\mathrm{m}^{3}$. Još i sektor Uslužne djelatnosti pri direktnom povećanju potrošnje svih sektora bilježi iznadprosječnu multiplikaciju potrošnje vode u iznosu od $12,8 \mathrm{~m}^{3}$.

\subsection{Analiza rezultata za 2010. godinu}

Direktna neto potrošnja u 2010. godini iznosila je $550.893 .000 \mathrm{~m}^{3}$ vode. Najveći direktni potrošač vode je sekundarni sektor, čija je direktna neto potrošnja iznosila $433.579 .000 \mathrm{~m}^{3}$. Slijede tercijarni, kvartarni i kvintarni sektor, koji su agregirani u jedan sektor, Uslužne djelatnosti, s količinom od $102.434 .000 \mathrm{~m}^{3}$, dok je primarni sektor 2010. godine direktno utrošio $14.880 .000 \mathrm{~m}^{3}$ vode. Isti sektori kao i 2004. godine imaju najveće vrijednosti ukupne intenzivnosti potrošnje vodnih resursa po jedinici outputa.

\subsubsection{Direktna neto potrošnja i direktna intenzivnost potrošnje vode u 2010. godini}

U 2010. godini sektor Proizvodnja koksa i rafiniranih naftnih proizvoda direktno utrošio najveće količine vode, u količinama od $143.794 .000 \mathrm{~m}^{3}$ vode, što je činilo 26,1\% ukupno utrošene količine. S udjelom od 24,7\%, drugi, apsolutno gledano, najveći direktni potrošač vode je sektor Opskrba električnom energijom, klimom, parom i klimatizacija, gdje je utrošeno 134.040.000 $\mathrm{m}^{3}$ vode. Treći najveći direktni potrošač vode jest sektor Uslužne djelatnosti, s količinama od 102.434.000 $\mathrm{m}^{3}$, što čini 19,5\% ukupne potrošnje. Vrijednosti direktne neto potrošnje za svaki sektor nalaze se u tablici 7 u Prilogu.

Najveće količine vode po milijun kuna outputa utrošeno je u sektoru Opskrba električnom energijom, plinom, parom i klimatizacija, u vrijednosti od $9.961 \mathrm{~m}^{3}$ / milijun HRK. Slijedi ga sektor Proizvodnja koksa i rafiniranih naftnih proizvoda, u kojem se za milijun HRK outputa direktno utroši $7.432 \mathrm{~m}^{3}$, dok treću vrijednost bilježi sektor Proizvodnja kemijskih i farmaceutskih proizvoda, koji direktno utroši $3.901 \mathrm{~m}^{3}$ / milijun HRK. Iako je po apsolutnim količinama sektor Uslužne djelatnosti treći najveći potrošač u 2010., zbog najvećeg ostvarenog outputa u 2010., po intenzivnosti direktne potrošnje vode taj je sektor na osmom mjestu s utroše- 
nom količinom vode od $281 \mathrm{~m}^{3}$ po milijun kuna outputa. Na dominantan udio sektora Proizvodnja koksa i rafiniranih naftnih proizvoda, Proizvodnja kemijskih i farmaceutskih proizvoda te Opskrba električnom energijom, plinom, parom i klimatizacijom u intenzivnosti direktne potrošnje vode ukazuje i vrijednost prosječne intenzivnosti direktne potrošnje, koja u 2010. iznosi $1.194 \mathrm{~m}^{3}$ po milijun kuna outputa. Još jedino sektor Proizvodnja ostalih nemetalnih mineralnih proizvoda bilježi iznadprosječnu vrijednost direktne intenzivnosti, u iznosu od $1.399 \mathrm{~m}^{3}$ vode po milijun kuna outputa. Na grafikonu 2 prikazani su direktna neto potrošnja i intenzivnost direktne potrošnje u 2010. godini.

\section{Grafikon 2:}

\section{DIREKTNA NETO POTROŠNJA I INTENZIVNOST POTROŠNJE PO SEKTORIMA U 2010. GODINI}

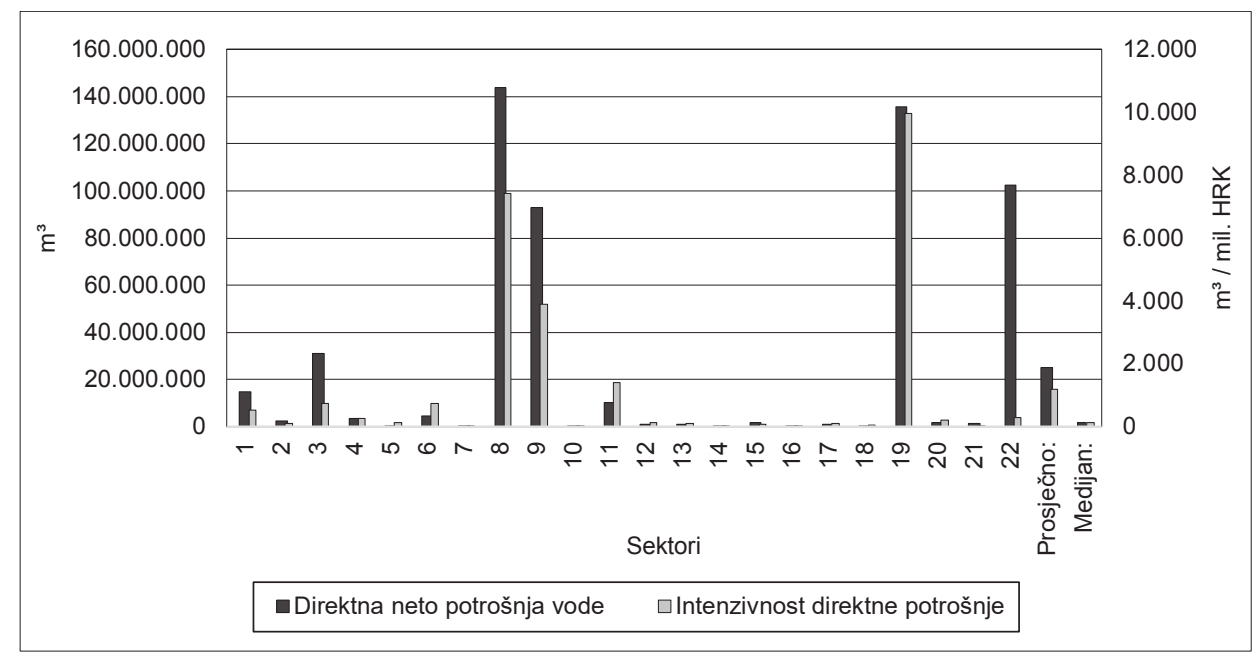

Izvor: izračun autora

Osim što su najmanji direktni neto potrošači vodnih resursa, sektori Proizvodnja motornih vozila, Proizvodnja proizvoda od gume i plastike te Tiskanje i srodne usluge ujedno bilježe najmanje vrijednosti direktne intenzivnosti potrošnje vode. Za sektore Proizvodnja prehrambenih i duhanskih proizvoda te Proizvodnja ostalih nemetalnih mineralnih proizvoda karakteristične su iznadprosječne vrijednosti jednog pokazatelja, a ispodprosječne vrijednosti drugog pokazatelja. Sektor Proizvodnja prehrambenih i duhanskih proizvoda troši iznadprosječne direktne količine vode u količini od $31.049 .000 \mathrm{~m}^{3}$, dok je zbog relativno visokog ostvarenog outputa intenzivnost direktne potrošnje tog sektora ispodprosječna, u iznosu 
od $748 \mathrm{~m}^{3}$ vode po milijun kuna outputa. Istovremeno sektor Proizvodnja ostalih nemetalnih mineralnih proizvoda troši ispodprosječne direktne količine vode $u$ količini od $10.169 .000 \mathrm{~m}^{3}$, dok je zbog relativno niskog ostvarenog outputa intenzivnost direktne potrošnje tog sektora iznadprosječna, u iznosu od $1.399 \mathrm{~m}^{3}$ vode po milijun kuna outputa.

\subsubsection{Međusektorski vodni tokovi i ukupna intenzivnost potrošnje vode u 2010. godini}

Sektor Tiskanje i srodne usluge po direktno neto količinama i direktnoj intenzivnosti potrošnje troši najmanje količine vode, no s intenzivnosti indirektne potrošnje od $1.134 \mathrm{~m}^{3} /$ mil. HRK ubraja se u sektore s iznadprosječnom indirektnom intenzivnosti potrošnje vode. U tablici 8 u Prilogu prikazani su intenzivnost indirektne potrošnje te intenzivnost ukupne potrošnje vode po sektorima u 2010. Sektor Opskrba električnom energijom, plinom, parom i klimatizacija ima najveću indirektnu intenzivnost potrošnje vode u iznosu od $2.544 \mathrm{~m}^{3}$ po milijun kuna outputa. Slijede sektori Tiskanje i srodne usluge s količinom $1.134 \mathrm{~m}^{3} /$ mil. HRK te Distribucija vode i gospodarenje otpadom s količinom $1.043 \mathrm{~m}^{3} / \mathrm{mil}$. HRK. Iznadprosječne vrijednosti indirektne potrošnje bilježe i sektori poput Građevinarstva s $897 \mathrm{~m}^{3} / \mathrm{mil}$. HRK, Proizvodnja ostalih nemetalnih mineralnih proizvoda s $859 \mathrm{~m}^{3} /$ mil. HRK, Proizvodnja kemijskih i farmaceutskih proizvoda s $864 \mathrm{~m}^{3} /$ mil. HRK te Uslužne djelatnosti sa $765 \mathrm{~m}^{3}$ / mil. HRK. Razmatrajući strukturu indirektne intenzivnosti, tj. intermedijarnih tokova svakog sektora pomoću matrice intermedijarnih tokova, koja je prikazana u Tablici 9 u Prilogu, za navedene se sektore, koje obilježava najveća indirektna intenzivnost potrošnje, može izvesti zajednički zaključak da se njihova indirektna potrošnja dominantno odnosi na sektore Proizvodnja koksa i rafiniranih naftnih proizvoda, Proizvodnja kemijskih i farmaceutskih proizvoda te Opskrba električnom energijom, plinom, parom i klimatizacija.

Sektor Opskrba električnom energijom, plinom, parom i klimatizacija za proizvodnju intermedijarnih inputa utroši najviše, tj. $4.902 \mathrm{~m}^{3}$ vode, dok slijede sektori Proizvodnja kemijskih i farmaceutskih proizvoda s potrošnjom od 3.632 $\mathrm{m}^{3}$ te Proizvodnja koksa i rafiniranih naftnih proizvoda s potrošnjom od 3.445 $\mathrm{m}^{3}$ po milijun kuna intermedijarnih inputa za proizvodnju jediničnog outputa svakog sektora. Sektor Uslužne djelatnosti indirektno utroše $1.360 \mathrm{~m}^{3}$ vode po milijun kuna outputa svih sektora, dok ostali sektori troše manje od $500 \mathrm{~m}^{3}$ vode po milijun kuna outputa svih sektora, što ukazuje na činjenicu da je utjecaj ostalih sektora na potrošnju vode, uzrokovanu proizvodnjom intermedijarnih inputa, značajno manja od utjecaja sektora Opskrba električnom energijom, pli- 
nom, parom i klimatizacijom, Proizvodnja kemijskih i farmaceutskih proizvoda te Proizvodnja koksa i rafiniranih naftnih proizvoda na potrošnju vode uslijed proizvodnje intermedijarnih inputa. Sektor Opskrba električnom energijom, plinom, parom i klimatizacija bilježi vrijednost ukupne intenzivnosti od 12.505 $\mathrm{m}^{3} /$ mil. HRK, Proizvodnja koksa i rafiniranih naftnih proizvoda vrijednost od $7.762 \mathrm{~m}^{3} / \mathrm{mil}$. HRK, Proizvodnja kemijskih i farmaceutskih proizvoda $4.746 \mathrm{~m}^{3}$ / mil. HRK te Proizvodnja ostalih nemetalnih mineralnih proizvoda $2.263 \mathrm{~m}^{3}$ / mil. HRK.

\subsubsection{Analiza multiplikatora ukupne i indirektne potrošnje u 2010.}

U tablici 10 u Prilogu prikazane su vrijednosti multiplikatora u 2010. godini. Sektor Tiskanje i srodne usluge, koji ima udio indirektne potrošnje od $97 \%$ u odnosu na ukupnu potrošnju, ima vrijednost multiplikatora ukupne potrošnje 38 , a indirektne potrošnje 37. Sektor Građevinarstvo, koji ima udio indirektne potrošnje od 96,6\% u odnosu na ukupnu potrošnju, bilježi drugu najveću vrijednost multiplikatora ukupne i indirektne potrošnje. Iako sektor Opskrba električnom energijom, plinom, parom i klimatizacija ima najveću vrijednost intenzivnosti indirektne potrošnje vode u iznosu od $2.544 \mathrm{~m}^{3} /$ mil. HRK, zbog dominantnog udjela intenzivnosti direktne potrošnje vode taj sektor bilježi vrijednost indirektnog multiplikatora 0,3 . U tablici 11 u Prilogu prikazana je raspodjela multiplikatora indirektne potrošnje pojedinog sektora na sve sektore. Primjerice, $1 \mathrm{~m}^{3}$ direktnog povećanja potrošnje vode u sektoru Tiskanje i srodne usluge, sektor Proizvodnja kemijskih i farmaceutskih proizvoda mora, za proizvodnju intermedijarnih inputa, dodatno potrošiti $13,873 \mathrm{~m}^{3}$ vode, a sektor Opskrbe električnom energijom, plinom, parom i klimatizacija 11,792 $\mathrm{m}^{3}$ vode. Sektori Opskrba električnom energijom, plinom, parom i klimatizacija, Proizvodnja kemijskih i farmaceutskih proizvoda te Proizvodnja koksa i rafiniranih proizvoda bilježe najveće vrijednosti indirektnog multiplikatora u iznosima od 48,3, 43,6 te 24,7.

\subsubsection{Usporedba rezultata za 2004. i 2010. godinu}

Usporede li se rezultati modela za promatrane godine, može se utvrditi da je u odnosu hrvatskog gospodarstva i vodnih resursa došlo do određenih promjena, no da je glavnina direktnih i indirektnih odnosa gospodarskih sektora i potrošnje vode ostala nepromijenjena. 
Za Primarni sektor može se utvrditi povećanje direktne neto potrošnje u 2010. u odnosu na 2004. sa 7.200.000 $\mathrm{m}^{3}$ na $14.880 .000 \mathrm{~m}^{3}$ vode. Iako se prema Hrvatskoj agenciji za okoliš i prirodu (2012.) tehnologija navodnjavanja nakon 2004. unaprijedila te smanjila specifična potrošnja po hektaru navodnjavane površine, glavnu razliku u količinama čine povećane količine utrošene Za ostale namjene. Kako je veličina outputa tog sektora u 2004. 23.383.000.000 HRK, a u 2010. 27.584.000.000 HRK, tako je intenzivnost direktne, a posljedično i ukupne intenzivnosti potrošnje u 2004. manja u odnosu na 2010., tj. u 2004 sektor Primarni sektor za milijun kuna outputa direktno i indirektno mora utrošiti 1.412 $\mathrm{m}^{3}$ voda. Analizom modela utvrđuje se smanjeni multiplikativni efekt povećanja direktne potrošnje vode u tom sektoru, tj. u 2004. bi za direktno povećanje potrošnje Primarnog sektora od $1 \mathrm{~m}^{3}$, ostali sektori morali potrošiti 3,6 m³ , dok bi u 2010 . ostali sektori potrošili $1,9 \mathrm{~m}^{3}$.

U sektorima Rudarstvo i vađenje, Proizvodnja prehrambenih i duhanskih proizvoda, Proizvodnja tekstila, odjeće, kože i srodnih proizvoda, Proizvodnja drva i proizvoda od drva te Proizvodnja papira i proizvoda od papira nije došlo do značajnih promjena. U sektoru Tiskanje i srodne usluge došlo je do značajnog smanjenja direktne neto potrošnje u 2010. u odnosu na 2004. godinu, gdje se direktna neto potrošnja smanjila sa $409.000 \mathrm{~m}^{3}$ na $103.000 \mathrm{~m}^{3}$. S obzirom na nepostojanje značajnih promjena u intermedijarnim odnosima tog sektora s ostalim sektorima i dominacijom indirektne potrošnje u odnosu na direktnu, multiplikator ukupne potrošnje vode povećao se u 2010. u odnosu na 2004., s 26,2 na 37,9. Kako je sektor Proizvodnja koksa i rafiniranih naftnih proizvoda najveći direktni neto potrošač u 2010., u odnosu na 2004. utvrđuje se veća efikasnost u proizvodnji outputa jer iako je došlo do povećanja outputa u 2010. u odnosu na 2004, direktna intenzivnost potrošnje u 2004. veća je u odnosu na 2010. S obzirom na strukturu matrice tehničkih koeficijenata i matrice intermedijarnih tokova potrošnje vode, koja se u značajnijoj mjeri nije promijenila, ukupna se intenzivnost potrošnje vode u tom sektoru u 2010. smanjila u odnosu na 2004., od $10.183 \mathrm{~m}^{3} / \mathrm{mil}$. HRK na $7.762 \mathrm{~m}^{3} / \mathrm{mil}$. HRK. Budući da je u ranijim analizama sektor Proizvodnja koksa i rafiniranih naftnih proizvoda okarakteriziran kao jedan od ključnih potrošača vodnih resursa u 2004. i 2010., važno je utvrditi da je u 2010. došlo do intenzivnijeg povećanja potrošnje vodnih resursa tog sektora uslijed jediničnog povećanja outputa svih sektora. U 2010. taj bi sektor u tom slučaju utrošio $3.632 \mathrm{~m}^{3}$ vode, dok je u 2004. godini ta količina $2.882 \mathrm{~m}^{3}$. Drugi ključan vodnopotrošački sektor u 2004. i 2010. je Proizvodnja kemijskih i farmaceutskih proizvoda, kod kojeg je došlo do smanjenja direktne neto potrošnje vode s 119.361 .000 na $92.903 .000 \mathrm{~m}^{3}$. S obzirom na činjenicu da je za promatrani sektor došlo do povećanja outputa, uz istovremeno smanjenje direktne potrošnje vode, utvrđuje se smanjenje ukupne intenzivnosti potrošnje vode s 7.792 u 2004. na $4.746 \mathrm{~m}^{3}$ vode po milijun kuna outputa u 2010. godini. Smanjenje utjecaja promatranog sektora na vodne resurse 
uslijed povećanja efikasnosti u proizvodnji, osim smanjenja direktne neto potrošnje, ukazuje i činjenica da bi za eventualno jedinično povećanje proizvodnje svih sektora, promatrani sektor u 2004. potrošio $5.577 \mathrm{~m}^{3}$, dok bi u 2010. potrošio 3.445 $\mathrm{m}^{3}$ vode. Sektor Proizvodnja proizvoda od gume i plastike karakterizira drastično smanjenje direktne neto potrošnje u 2010., kad se trošilo $107.000 \mathrm{~m}^{3} \mathrm{u}$ odnosu na $1.785 .000 \mathrm{~m}^{3}$ u 2004.

Iako je u sektorima Proizvodnja ostalih nemetalnih mineralnih proizvoda, Proizvodnja metala, Proizvodi od metala, osim strojeva i opreme, Proizvodnja strojeva i uređaja, Proizvodnja elektroničke i električne opreme, Proizvodnja motornih vozila, Proizvodnja ostalih prijevoznih sredstava, Proizvodnja namještaja te Građevinarstvo došlo do određenih promjena u direktnoj neto potrošnji, značajka nabrojanih sektora je relativno mali utjecaj na potrošnju vodnih resursa u obje promatrane godine. Kao treći ključan vodnopotrošački sektor apostrofiran je sektor Opskrba električnom energijom, plinom, parom i klimatizacija. Iako je direktna neto potrošnja u 2004. veća u odnosu na 2010., ukupna intenzivnost potrošnje promatranog sektora veća je u 2010. godini te iznosi $12.505 \mathrm{~m}^{3} \mathrm{u}$ odnosu na 10.277 $\mathrm{m}^{3}$ po milijun kuna outputa. Analizom intermedijarnih vodnih tokova utvrđuje se da u 2004. promatrani sektor uslijed jediničnog povećanja outputa svih sektora troši 9.076, dok u 2010. troši $4.920 \mathrm{~m}^{3}$ vode. Glavni razlog smanjenja indirektne potrošnje sektora Opskrba električnom energijom, plinom, parom i klimatizacija jest u tome da u 2010. dolazi do značajnog smanjenja samopotrošnje promatranog sektora. Drugim riječima, u 2010. promatrani sektor pri proizvodnji intermedijarnih inputa korištenih u proizvodnji tog istog sektora troši upola manje količine vode nego u odnosu na 2004.

U sektoru Distribucija vode i gospodarenje otpadom u 2004. direktno neto potrošnja iznosila je $7.102 .000 \mathrm{~m}^{3}$, dok je u 2010. direktno neto potrošnja smanjena na $1.775 .000 \mathrm{~m}^{3}$ vode. S obzirom na neznatne promjene u intermedijarnim tokovima vodnih resursa, $u$ 2004. je ukupna intenzivnost potrošnje vode u promatranom sektoru iznosila $4.100 \mathrm{~m}^{3}$ vode po milijun kuna outputu, dok je u 2010. ona smanjena na $1.242 \mathrm{~m}^{3}$ po milijun kuna outputa. Značajne promjene u direktnoj neto potrošnji zabilježene su u sektoru Uslužne djelatnosti, u kojem se 2004. direktno neto utrošilo $65.150 .000 \mathrm{~m}^{3}$ vode, dok se u 2010. utrošilo $102.434 .000 \mathrm{~m}^{3}$. Kako se u međuvremenu output povećao s 249.789.000.000 HRK na 364.554.000.000 HRK, tako su intenzivnost indirektne i ukupne potrošnje te multiplikatori potrošnje neznatno promijenjeni. Isto vrijedi i za povećanje potrošnje navedenog sektora uslijed jediničnog povećanja outputa svih sektora. U tom slučaju, u 2004. utrošilo bi se dodatnih $1.238 \mathrm{~m}^{3}$, a u 2010. $1.360 \mathrm{~m}^{3}$ vode. 


\subsubsection{Ograničenja hibridnog input-output modela potrošnje vode}

Ograničenja osnovnog input-output modela u mnogome određuju ograničenja hibridnog modela. Među njima je svakako konstantnost tehničkih koeficijenata. Pretpostavka o neograničenosti proizvodnih kapaciteta sugerira da je ponuda intermedijarnih i finalnih proizvoda, u hibridnom modelu vodnih resursa, neograničena i savršeno elastična. Hibridnim se modelom gospodarstvo države agregira na određeni broj sektora, gdje razina agregacije utječe na detaljnost rezultata. Agregiranjem velikog broja srodnih djelatnosti u jedan modelski sektor, zanemaruje se činjenica da te djelatnosti nemaju jednaku tehnologiju proizvodnje i strukturu inputa. Budući da je intencija modela za 2004. i 2010. godinu usporedba rezultata te analiza trendova u potrošnji vodnih resursa za potrebe hrvatskog gospodarstva, modeli imaju jednake modelske sektore nastale sjedinjavanjem djelatnosti prema različitim NKD-ovima, čime se utjecalo na detaljnost matrice tehničkih koeficijenata, samim time i na matricu intermedijarnih vodnih tokova. $\mathrm{S}$ obzirom na to da se za potrebe modela koriste monetarni i nemonetarni podaci, također je i dostupnost potrebnih nemonetarnih, tj. fizičkih, podataka u mnogome je utjecala na razinu agregacije. Zbog neusklađenosti podataka o potrošnji vode $u$ gospodarske svrhe za pojedine sektore prema NKD-u, pri agregaciji sektora moralo se voditi računa o većoj razini sjedinjavanja u odnosu na input-output tablicu. Drugim riječima, u predstavljenom modelu sve su djelatnosti iz tercijarnog, kvartarnog i kvintarnog sektora sjedinjenje u jedan sektor, Uslužne djelatnosti, čime se utjecalo na kvalitetu rezultata modela jer se modelom ne može utvrditi direktna i indirektna intenzivnost potrošnje za svaku od djelatnosti iz spomenutih sektora. Za modelski Primarni sektor i Građevinarstvo u modelu su se procjenjivale direktno utrošene količine vode zbog nepostojanja preciznih podataka o korištenju vodnih resursa u industriji za promatranu godinu.

\section{ZAKLJUČAK}

Za potrebe hibridnog modela za 2004. i 2010. godinu, temeljem dostupnosti relevantnih monetarnih i nemonetarnih podataka, formirana su 22 gospodarska sektora, na koje je cjelokupno gospodarstvo Hrvatske raščlanjeno. Analizom rezultata oba modela utvrđuje se da je gospodarstvo Hrvatske u 2004. i 2010. godini zadržalo homogenu strukturu, tj. glavninu pritiska na vodne resurse čine industrijski sektori koji se tiču proizvodnje električne energije, koksa i rafiniranih naftnih proizvoda te kemijskih i farmaceutskih proizvoda. Primjerice, u 2004. godini čak $74 \%$, a u 2010. $68 \%$ od ukupnih direktno utrošenih količina vode otpada na spo- 
menute sektore. Osim direktno utrošenih količina vode, za spomenute su sektore karakteristične i najveće vrijednosti indirektne potrošnje vode, na način da troše najveće količine vode pri proizvodnji intermedijarnih inputa za ostale sektore u hrvatskom gospodarstvu. To znači da se preko proizvodnje proizvoda i usluga navedenih sektora voda dominantno distribuira po ostalim sektorima na koje je gospodarstvo Hrvatske raščlanjeno. Analizom multiplikatora potrošnje vode utvrđuje se da bi jedinično povećanje direktne potrošnje vode, uslijed ekspanzije gospodarskih aktivnosti u Hrvatskoj, svih sektora u gospodarstvu Hrvatske dovelo do dominantnog multipliciranja potrošnje vode u sektorima proizvodnje električne energije, koksa i rafiniranih naftnih proizvoda te kemijskih i farmaceutskih proizvoda. Kako nabrojani sektori osim najvećeg direktnog utjecaja imaju i dominantan indirektan utjecaj na vodne resurse, zaključuje se da bi se smanjenje utjecaja na vodne resurse postiglo povećanjem efikasnosti proizvodnje u spomenutim sektorima. Vodno intenzivni sektori, direktno i indirektno, istovjetni su sektorima koje je za Hrvatsku dobio Čegar (2020.) na temelju podataka za 2010. godinu. Analize se inače razlikuju od zemlje do zemlje. Kod većine je direktno vodno intenzivan sektor poljoprivrede a indirektno različiti industrijski sektori (industrija drva i papira, kemijska industrija, industrija hrane,...) i uslužni sektori (hoteli i restorani). Hrvatska se razlikuje od navedenih zemalja jer su sektori koji su direktno vodno intenzivni ujedno i indirektno vodno najintenzivniji.

Ograničenja osnovnog input-output modela u mnogome određuju ograničenja hibridnog modela. Među njima je svakako konstantnost tehničkih koeficijenata. Pretpostavka o neograničenosti proizvodnih kapaciteta sugerira da je ponuda intermedijarnih i finalnih proizvoda, u hibridnom modelu vodnih resursa, neograničena i savršeno elastična. Hibridnim se modelom gospodarstvo države agregira na određeni broj sektora, gdje razina agregacije utječe na detaljnost rezultata. Agregiranjem velikog broja srodnih djelatnosti u jedan modelski sektor, zanemaruje se činjenica da te djelatnosti nemaju jednaku tehnologiju proizvodnje i strukturu inputa. Budući da je intencija modela za 2004. i 2010. godinu usporedba rezultata te analiza trendova u potrošnji vodnih resursa za potrebe hrvatskog gospodarstva, modeli imaju jednake modelske sektore nastale sjedinjavanjem djelatnosti prema različitim NKD-ovima, čime se utjecalo na detaljnost matrice tehničkih koeficijenata, samim time i na matricu intermedijarnih vodnih tokova. S obzirom na to da se za potrebe modela koriste monetarni i nemonetarni podaci, također je i dostupnost potrebnih nemonetarnih, tj. fizičkih, podataka u mnogome je utjecala na razinu agregacije. Zbog neusklađenosti podataka o potrošnji vode $u$ gospodarske svrhe za pojedine sektore prema NKD-u, pri agregaciji sektora moralo se voditi računa o većoj razini sjedinjavanja u odnosu na input-output tablicu. Drugim riječima, u predstavljenom modelu sve su djelatnosti iz tercijarnog, kvartarnog i kvintarnog sektora sjedinjenje u jedan sektor, Uslužne djelatnosti, čime se utjecalo na kvalitetu rezultata modela jer se modelom ne može utvrditi direktna 
i indirektna intenzivnost potrošnje za svaku od djelatnosti iz spomenutih sektora. Za modelski Primarni sektor i Građevinarstvo u modelu su se procjenjivale direktno utrošene količine vode zbog nepostojanja preciznih podataka o korištenju vodnih resursa u industriji za promatranu godinu.

Buduća istraživanja svakako će obuhvatiti i 2015. godinu s obzirom na dostupnost I-O tablice i podatke o potrošnji vode te vidjeti da li su se i koje promjene dogodile u strukturi hrvatskog gospodarstva s obzirom na potrošnju vode i vodnu intenzivnost pojedinih sektora. Za očekivati je da nema značajnijih odstupanja u odnosu na rezultate za 2004. i 2010. godinu jer se struktura gospodarstva nije značajnije promijenila u razdoblju od 5 godina, 2015. u odnosu na 2010. godinu a prekratko je razdoblje da bi ulaskom u EU 1. srpnja 2013. godine određeni gospodarski sektori ostvarili značajnija ulaganja i povećali učinkovitost uporabe voda.

\section{LITERATURA}

1. AQUASTAT, 2018., Dostupno na http://www.fao.org/nr/water/aquastat/water_res/index.stm\#cp

2. Babić, M. (1990.). Osnove input-output analize, 3. dopunjeno izdanje, Zagreb: Narodne novine.

3. Bobylev, S.N., Kudryavtseva, O.V., Yakovleva, Ye.Yu. (2013.). Green economy: Regional priorities. Dostupno na http://r-economy.ru/wp-content/ uploads/2015/10/10_Bobylev.pdf

4. Boudhar, A. i ostali, (2017.). An input-output framework for analysing relationships between economic sectors and water use and intersectoral water relationships in Morocco, Journal of Economic Structures: Sprinter Open.

5. Čegar, S. (2016.). Utjecaj međusektorskih odnosa na potrošnju i onečišćenje vode u gospodarstvu Republike Hrvatske, Doktorski rad, Rijeka: Ekonomski fakultet.

6. Čegar, S. (2020), Water extended input-output analysis of the Croatian economy. Zbornik radova Ekonomskog fakulteta Rijeka. vol. 38, no. 1, p. 147-182. Dostupno na https://hrcak.srce.hr/index.php?show=clanak\&id_clanak_jezik=348670

7. Davie, T. (2008.). Fundamentals of Hydrology, Second Edition, New York: Routledge

8. Deng, X., Zhang, F., Wang,. Z., Li, X., Zhang, T. (2014). An Extended Input Output Table Compiled for Analyzing Water Demand and Consumption at County Level in China. Sustainability 6, p. 3301-3320. 
9. Duarte, R., Sacnchez-Choliz, J., Bielsa J. (2002.). Water use in the Spanish economy: an input/output approach, Ecological Economics 43 p. 71/85.

10. Državni zavod za statistiku, https://www.dzs.hr/

11. EEA, 2012. Dostupno na: https://www.eea.europa.eu/articles/water-for-agriculture.

12. EUROSTAT, 2017. Dostupno na http://ec.europa.eu/eurostat/statistics-explained/index.php/Water_statistics

13. FAO. 2016., AQUASTAT baza podataka, Dostupno na http://www.fao.org/nr/ water/aquastat/data/query/index.html?lang=en

14. Gelo, T., Družić, M. (2016.). Sektorska struktura gospodarstva Hrvatske. U:Obadić, A. i Tica J., ur., Gospodarstvo Hrvatske, Zagreb: Ekonomski fakultet Sveučilišta u Zagrebu

15. Hanslmeier, A. (2011.). Water in the Universe: Water on Earth, Properties of Water, Springer: Springer Science+Business Media.

16. HAOP (2012.). Izvješće o stanju okoliša u Republici Hrvatskoj za razdoblje 2005.-2008., Agencija za zaštitu okoliša, Zagreb. Dostupno na http://www. haop.hr/sites/default/files/uploads/dokumenti/06_integrirane/dokumenti/niso/ IzvjeIzv\%20o\%20stanju\%20okolisa\%20u\%20RH_2005-2008.pdf

17. HAOP (2014.). Izvješće o stanju okoliša u Republici Hrvatskoj, 2014. (razdoblje od 2009. do 2012.), Agencija za zaštitu okoliša, Zagreb. Dostupno na http://www.haop.hr/sites/default/files/uploads/dokumenti/06_integrirane/dokumenti/niso/IzvjeIzv\%20o\%20stanju\%20okolisa\%20u\%20 RH_2014.pdf.

18. Hartman, L.M. (1965.). Efficiency criteria for market transfers of water; Dostupno na https://agupubs.onlinelibrary.wiley.com/doi/abs/10.1029/ WR001i002p00165

19. Hristov, J., i ostali (2012.). Input-Output analysis for water consumption in Macedonia, European summer school in resource and Environmental Economics: Management of International Water, 1-7 July, 2012 - Venice, Italy.

20. Kobayashi, Y., Oyasato, N. (2008). An estimation of embodied intensity of water consumption in Japan based on input-output analysis method, Journal of Life Cycle Assessment, Japan, 4(4), 359-366. Dostupno na https://www. jstage.jst.go.jp/article/lca/4/4/4_359/_article

21. Leistritz, F.L., Leitch, J., Bangsund, D., (2002). Regional economic impacts of water management alternatives: the case of Devils Lake, North Dakota, USA, Journal of environmental management, 66(4), pp. 465-473. Dostupno na https://www.sciencedirect.com/science/article/pii/S0301479702906006 
22. Lenton, R., Muller, M. (2009.). Integrated water resources management in practice:, Better water management for development, London: Earthscan.

23. Lenzen, M., Foran, B. (2001.). An input-output analysis of Australian water usage. Dostupno na https://www.researchgate.net/publication/250140351_An_ input-output_analysis_of_Australian_water_usage

24. Leontief, W. (1986.). Input-Output Economics: Input-output analysis, Second Edition, Oxford: Oxford University Press.

25. Miller, R.E., Blair, P.D (2009.). Input-Output Analysis; Foundations and Extensions, Second edition, Cambridge: Cambridge University Press.

26. Okadera, T., Watanabe, M., Xu, K. (2008.). Analysis of water demand and water pollutant discharge using a regional input-output table: An application to the City of Chongqing, upstream of the Three Gorges Dam in China. Dostupno na https://www.researchgate.net/publication/224892276_Analysis_ of_water_demand_and_water_pollutant_discharge_using_a_regional_inputoutput_table_An_application_to_the_City_of_Chongqing_upstream_of_the Three_Gorges_Dam_in_China

27. Perry, C.J., Rock, M., Seckler, D., (1997.). Water as an Economic Good: A Solution, or a Problem?, Research Report 14. Colombo, Sri Lanka: International Irrigation Management Institute.

28. Qin, C., Su, Z., Bressers, J. T. A., Jia, Y., \& Wang, H., (2013.). An analysis of water consumption and pollution with an input-output model in the Haihe river basin, China. Advanced materials research, 864-867, 1059-1069.

29. Savenije, H.H.G. (2002.). Why water is not an ordinary economic good, or why the girl is special, Physics and Chemistry of the Earth 27, 741-744.

30. Strategija upravljanja vodama, 2009., Hrvatske vode, Zagreb.

31. UN (1992.). The Dublin Statement on Water and Sustainable Development. Dostupno na http://www.un-documents.net/h2o-dub.htm

32. UN (2003.). Review of world water resources by country, Food and Agriculture Organization of the United Nations, Rim.

33. UN (2012.). System of Environmental-Economic Accounting for Water, Department of Economic and Social Affairs, Statistics Division, New York.

34. Yu, Y., Hubacek, K., Feng, K. and Guan, D. (2010). Assessing regional and global water footprints for the UK, Ecological Economics, 69 (5). Dostupno na: https://geog.umd.edu/sites/geog.umd.edu/files/pubs/UK\%20water\%20footprint.pdf 


\section{PRILOZI}

\section{Tablica 1:}

\section{RAŠČLANJIVANJE HRVATSKOG GOSPODARSTVA NA 22 SEKTORA KOJA SE KORISTE U MODELU}

\begin{tabular}{|c|c|c|}
\hline $\mathrm{Br}$. & Ime sektora & Klasifikacija sektora \\
\hline 1 & Primarni sektor & Primarni sektor \\
\hline 2 & Rudarstvo i vađenje & \multirow{20}{*}{ Sekundarni sektor } \\
\hline 3 & Proizvodnja prehrambenih i duhanskih proizvoda & \\
\hline 4 & Proizvodnja tekstila, odjeće, kože i srodnih proizvoda & \\
\hline 5 & Proizvodnja drva i proizvoda od drva, osim namještaja & \\
\hline 6 & Proizvodnja papira i proizvoda od papira & \\
\hline 7 & Tiskanje i srodne usluge & \\
\hline 8 & Proizvodnja koksa i rafiniranih naftnih proizvoda & \\
\hline 9 & Proizvodnja kemijskih i farmaceutskih proizvoda & \\
\hline 10 & Proizvodnja proizvoda od gume i plastike & \\
\hline 11 & Proizvodnja ostalih nemetalnih mineralnih proizvoda & \\
\hline 12 & Proizvodnja metala & \\
\hline 13 & Proizvodi od metala, osim strojeva i opreme & \\
\hline 14 & Proizvodnja strojeva i uređaja & \\
\hline 15 & Proizvodnja elektroničke i električne opreme & \\
\hline 16 & Proizvodnja motornih vozila & \\
\hline 17 & Proizvodnja ostalih prijevoznih sredstava & \\
\hline 18 & Proizvodnja namještaja & \\
\hline 19 & Opskrba električnom energijom, plinom, parom i klimatizacija & \\
\hline 20 & Distribucija vode i gospodarenje otpadom & \\
\hline 21 & Građevinarstvo & \\
\hline 22 & Uslužne djelatnosti & $\begin{array}{c}\text { Tercijarni,/kvartarni/ } \\
\text { kvintarni }\end{array}$ \\
\hline
\end{tabular}

Izvor: obrada autora 
T. GELO, D. KNEZ: Primjena input-output modela u analizi potrošnje vode kao inputa u gospodarstvu Hrvatske EKONOMSKI PREGLED, 72 (2) 272-307 (2021)

Tablica 2:

\section{DIREKTNA NETO POTROŠNJA VODE I INTENZIVNOST POTROŠNJE VODE U 2004. GODINI PO SEKTORIMA}

\begin{tabular}{|c|c|c|c|c|c|}
\hline & Sektor & $\begin{array}{c}\text { Direktna } \\
\text { potrošnja vode } \\
{\left[000 \mathrm{~m}^{3}\right]}\end{array}$ & $\begin{array}{l}\text { Udio } \\
{[\%]}\end{array}$ & $\begin{array}{c}\text { Ukupni } \\
\text { output } \\
\text { [mil. } \\
\text { HRK] }\end{array}$ & $\begin{array}{c}\text { Intenzivnost } \\
\text { direktne } \\
\text { potrošnje } \\
{\left[\mathrm{m}^{3} / \text { mil. HRK] }\right.}\end{array}$ \\
\hline 1 & Primarni sektor & 7.200 & $1,4 \%$ & 23.384 & 308 \\
\hline 2 & Rudarstvo i vađenje & 1.981 & $0,4 \%$ & 17.197 & 115 \\
\hline 3 & $\begin{array}{l}\text { Proizvodnja prehrambenih i duhanskih } \\
\text { proizvoda }\end{array}$ & 31.009 & $5,9 \%$ & 33.626 & 922 \\
\hline 4 & $\begin{array}{l}\text { Proizvodnja tekstila, odjeće, kože i srodnih } \\
\text { proizvoda }\end{array}$ & 4.303 & $0,8 \%$ & 14.855 & 290 \\
\hline 5 & $\begin{array}{l}\text { Proizvodnja drva i proizvoda od drva osim } \\
\text { namještaja }\end{array}$ & 642 & $0,1 \%$ & 5.633 & 114 \\
\hline 6 & Proizvodnja papira i proizvoda od papira & 5.035 & $1,0 \%$ & 4.844 & 1.039 \\
\hline 7 & Tiskanje i srodne usluge & 409 & $0,1 \%$ & 7.999 & 51 \\
\hline 8 & $\begin{array}{l}\text { Proizvodnja koksa i rafiniranih naftnih } \\
\text { proizvoda }\end{array}$ & 123.714 & $23,6 \%$ & 12.838 & 9.637 \\
\hline 9 & $\begin{array}{l}\text { Proizvodnja kemijskih i farmaceutskih } \\
\text { proizvoda }\end{array}$ & 119.361 & $22,7 \%$ & 19.225 & 6.209 \\
\hline 10 & Proizvodnja proizvoda od gume i plastike & 1.785 & $0,3 \%$ & 6.674 & 267 \\
\hline 11 & $\begin{array}{l}\text { Proizvodnja ostalih nemetalnih mineralnih } \\
\text { proizvoda }\end{array}$ & 5.014 & $1,0 \%$ & 9.900 & 506 \\
\hline 12 & Proizvodnja metala & 3.286 & $0,6 \%$ & 8.409 & 391 \\
\hline 13 & Proizvodi od metala, osim strojeva i opreme & 688 & $0,1 \%$ & 10.584 & 65 \\
\hline 14 & Proizvodnja strojeva i uređaja & 560 & $0,1 \%$ & 18.337 & 31 \\
\hline 15 & Proizvodnja elektroničke i električne opreme & 605 & $0,1 \%$ & 18.757 & 32 \\
\hline 16 & Proizvodnja motornih vozila & 157 & $0,0 \%$ & 10.297 & 15 \\
\hline 17 & Proizvodnja ostalih prijevoznih sredstava & 1.890 & $0,4 \%$ & 11.207 & 169 \\
\hline 18 & Proizvodnja namještaja & 500 & $0,1 \%$ & 5.983 & 84 \\
\hline 19 & $\begin{array}{l}\text { Opskrba električnom energijom, plinom, } \\
\text { parom i klimatizacija }\end{array}$ & 143.219 & $27,3 \%$ & 19.123 & 7.489 \\
\hline 20 & Distribucija vode i gospodarenje otpadom & 7.102 & $1,4 \%$ & 2.990 & 2.375 \\
\hline 21 & Građevinarstvo & 1.350 & $0,3 \%$ & 45.614 & 30 \\
\hline \multirow[t]{3}{*}{22} & Uslužne djelatnosti & 65.150 & $12,4 \%$ & 249.787 & 261 \\
\hline & Prosječno: & 23.861 & & 25.330 & 1.382 \\
\hline & Medijan: & 2.633 & & 12.022 & 264 \\
\hline
\end{tabular}

Izvor: izračun autora 
Tablica 3:

\section{INTENZIVNOST INDIREKTNE I UKUPNE POTROŠNJE VODE PO SEKTORIMA U 2004.}

\begin{tabular}{|c|c|c|c|c|}
\hline & Sektor & $\begin{array}{c}\text { Intenzivnost } \\
\text { indirektne } \\
\text { potrošnje vode } \\
{\left[\mathrm{m}^{3} / \text { mil. HRK }\right]}\end{array}$ & $\begin{array}{c}\text { Ukupna } \\
\text { intenzivnost } \\
\text { potrošnje vode } \\
{\left[\mathrm{m}^{3} / \text { mil. HRK }\right]}\end{array}$ & $\begin{array}{l}\text { Udio indirektne } \\
\text { intenzivnosti } \\
\text { potrošnje vode }\end{array}$ \\
\hline 1 & Primarni sektor & 1.104 & 1.412 & $78 \%$ \\
\hline 2 & Rudarstvo i vađenje & 525 & 641 & $82 \%$ \\
\hline 3 & $\begin{array}{l}\text { Proizvodnja prehrambenih i duhanskih } \\
\text { proizvoda }\end{array}$ & 1.033 & 1.955 & $53 \%$ \\
\hline 4 & $\begin{array}{l}\text { Proizvodnja tekstila, odjeće, kože i srodnih } \\
\text { proizvoda }\end{array}$ & 396 & 685 & $58 \%$ \\
\hline 5 & $\begin{array}{l}\text { Proizvodnja drva i proizvoda od drva osim } \\
\text { namještaja }\end{array}$ & 861 & 975 & $88 \%$ \\
\hline 6 & Proizvodnja papira i proizvoda od papira & 968 & 2.007 & $48 \%$ \\
\hline 7 & Tiskanje i srodne usluge & 1.289 & 1.341 & $96 \%$ \\
\hline 8 & $\begin{array}{l}\text { Proizvodnja koksa i rafiniranih naftnih } \\
\text { proizvoda }\end{array}$ & 546 & 10.183 & $5 \%$ \\
\hline 9 & $\begin{array}{l}\text { Proizvodnja kemijskih i farmaceutskih } \\
\text { proizvoda }\end{array}$ & 1.584 & 7.792 & $20 \%$ \\
\hline 10 & Proizvodnja proizvoda od gume i plastike & 1.352 & 1.620 & $83 \%$ \\
\hline 11 & $\begin{array}{l}\text { Proizvodnja ostalih nemetalnih mineralnih } \\
\text { proizvoda }\end{array}$ & 1.643 & 2.150 & $76 \%$ \\
\hline 12 & Proizvodnja metala & 412 & 803 & $51 \%$ \\
\hline 13 & Proizvodi od metala, osim strojeva i opreme & 715 & 780 & $92 \%$ \\
\hline 14 & Proizvodnja strojeva i uređaja & 339 & 369 & $92 \%$ \\
\hline 15 & Proizvodnja elektroničke i električne opreme & 559 & 591 & $95 \%$ \\
\hline 16 & Proizvodnja motornih vozila & 52 & 67 & $77 \%$ \\
\hline 17 & Proizvodnja ostalih prijevoznih sredstava & 748 & 917 & $82 \%$ \\
\hline 18 & Proizvodnja namještaja & 555 & 638 & $87 \%$ \\
\hline 19 & $\begin{array}{l}\text { Opskrba električnom energijom, plinom, } \\
\text { parom i klimatizacija }\end{array}$ & 2.788 & 10.277 & $27 \%$ \\
\hline 20 & Distribucija vode i gospodarenje otpadom & 1.725 & 4.100 & $42 \%$ \\
\hline 21 & Građevinarstvo & 1.096 & 1.126 & $97 \%$ \\
\hline \multirow[t]{3}{*}{22} & Uslužne djelatnosti & 705 & 966 & $73 \%$ \\
\hline & Prosječno: & 954 & 2.336 & \\
\hline & Medijan: & 805 & 1.051 & \\
\hline
\end{tabular}

Izvor: izračun autora 
T. GELO, D. KNEZ: Primjena input-output modela u analizi potrošnje vode kao inputa u gospodarstvu Hrvatske EKONOMSKI PREGLED, 72 (2) 272-307 (2021)

Tablica 4:

MEĐUSEKTORSKI VODNI TOKOVI ZA POJEDINE SEKTORE U 2004.

\begin{tabular}{|c|c|c|c|c|c|c|c|c|c|c|}
\hline & $\mathrm{W}$ & 1 & 3 & 7 & 9 & 10 & 11 & 19 & 20 & 21 \\
\hline 1 & Primarni sektor & 73 & 86 & 3 & 1 & 3 & 2 & 3 & 2 & 4 \\
\hline 2 & Rudarstvo i vađenje & 3 & 3 & 3 & 7 & 2 & 13 & 42 & 7 & 10 \\
\hline 3 & $\begin{array}{l}\text { Proizvodnja prehrambenih i duhanskih } \\
\text { proizvoda }\end{array}$ & 104 & 138 & 8 & 3 & 4 & 5 & 7 & 6 & 8 \\
\hline 4 & $\begin{array}{l}\text { Proizvodnja tekstila, odjeće, kože i } \\
\text { srodnih proizvoda }\end{array}$ & 1 & 1 & 2 & 0 & 1 & 1 & 1 & 1 & 1 \\
\hline 5 & $\begin{array}{l}\text { Proizvodnja drva i proizvoda od drva osim } \\
\text { namještaja }\end{array}$ & 0 & 0 & 0 & 0 & 1 & 1 & 1 & 1 & 5 \\
\hline 6 & Proizvodnja papira i proizvoda od papira & 14 & 35 & 157 & 6 & 6 & 11 & 5 & 9 & 5 \\
\hline 7 & Tiskanje i srodne usluge & 0 & 0 & 1 & 0 & 0 & 0 & 0 & 0 & 0 \\
\hline 8 & $\begin{array}{l}\text { Proizvodnja koksa i rafiniranih naftnih } \\
\text { proizvoda }\end{array}$ & 196 & 106 & 82 & 82 & 43 & 155 & 926 & 183 & 282 \\
\hline 9 & $\begin{array}{l}\text { Proizvodnja kemijskih i farmaceutskih } \\
\text { proizvoda }\end{array}$ & 450 & 235 & 570 & 1.097 & 1.019 & 243 & 84 & 126 & 232 \\
\hline 10 & Proizvodnja proizvoda od gume i plastike & 5 & 8 & 11 & 5 & 16 & 2 & 1 & 1 & 4 \\
\hline 11 & $\begin{array}{l}\text { Proizvodnja ostalih nemetalnih } \\
\text { mineralnih proizvoda }\end{array}$ & 3 & 9 & 4 & 2 & 4 & 73 & 6 & 7 & 59 \\
\hline 12 & Proizvodnja metala & 1 & 2 & 4 & 1 & 8 & 8 & 2 & 13 & 23 \\
\hline 13 & $\begin{array}{l}\text { Proizvodi od metala, osim strojeva i } \\
\text { opreme }\end{array}$ & 0 & 1 & 0 & 0 & 0 & 1 & 0 & 6 & 3 \\
\hline 14 & Proizvodnja strojeva i uređaja & 0 & 0 & 0 & 0 & 0 & 0 & 0 & 0 & 0 \\
\hline 15 & $\begin{array}{l}\text { Proizvodnja elektroničke i električne } \\
\text { opreme }\end{array}$ & 0 & 0 & 0 & 0 & 0 & 0 & 0 & 0 & 1 \\
\hline 16 & Proizvodnja motornih vozila & 0 & 0 & 0 & 0 & 0 & 0 & 0 & 0 & 0 \\
\hline 17 & Proizvodnja ostalih prijevoznih sredstava & 0 & 0 & 1 & 0 & 0 & 0 & 0 & 0 & 0 \\
\hline 18 & Proizvodnja namještaja & 0 & 0 & 0 & 0 & 0 & 0 & 0 & 0 & 0 \\
\hline 19 & $\begin{array}{l}\text { Opskrba električnom energijom, } \\
\text { plinom, parom i klimatizacija }\end{array}$ & 186 & 338 & 336 & 341 & 209 & 1.057 & 1.620 & 1.260 & 348 \\
\hline 20 & Distribucija vode i gospodarenje otpadom & 5 & 6 & 9 & 2 & 2 & 6 & 5 & 8 & 32 \\
\hline 21 & Građevinarstvo & 0 & 0 & 1 & 0 & 0 & 2 & 2 & 2 & 6 \\
\hline \multirow[t]{2}{*}{22} & Uslužne djelatnosti & 61 & 63 & 99 & 35 & 32 & 62 & 80 & 90 & 73 \\
\hline & Intenzitet indirektne potrošnje vode & 1.104 & 1.033 & 1.289 & 1.584 & 1.352 & 1.643 & 2.788 & 1.725 & 1.096 \\
\hline
\end{tabular}

Izvor: izračun autora 
Tablica 5:

UKUPNI I INDIREKTNI MULTIPLIKATORI U 2004.

\begin{tabular}{|c|l|c|c|}
\hline \multicolumn{1}{|c|}{ Sektor } & $\begin{array}{c}\text { Ukupni } \\
\text { multiplikator } \\
{[1]}\end{array}$ & $\begin{array}{c}\text { Indirektni } \\
\text { multiplikator } \\
{[1]}\end{array}$ \\
\hline 1 & Primarni sektor & 4,6 & 3,6 \\
\hline 2 & Rudarstvo i vađenje & 5,6 & 4,6 \\
\hline 3 & Proizvodnja prehrambenih i duhanskih proizvoda & 2,1 & 1,1 \\
\hline 4 & Proizvodnja tekstila, odjeće, kože i srodnih proizvoda & 2,4 & 1,4 \\
\hline 5 & Proizvodnja drva i proizvoda od drva osim namještaja & 8,6 & 7,6 \\
\hline 6 & Proizvodnja papira i proizvoda od papira & 1,9 & 0,9 \\
\hline 7 & Tiskanje i srodne usluge & 26,2 & 25,2 \\
\hline 8 & Proizvodnja koksa i rafiniranih naftnih proizvoda & 1,1 & 0,1 \\
\hline 9 & Proizvodnja kemijskih i farmaceutskih proizvoda & 1,3 & 0,3 \\
\hline 10 & Proizvodnja proizvoda od gume i plastike & 6,1 & 5,1 \\
\hline 11 & Proizvodnja ostalih nemetalnih mineralnih proizvoda & 4,2 & 3,2 \\
\hline 12 & Proizvodnja metala & 2,1 & 1,1 \\
\hline 13 & Proizvodi od metala, osim strojeva i opreme & 12,0 & 11,0 \\
\hline 14 & Proizvodnja strojeva i uređaja & 12,1 & 11,1 \\
\hline 15 & Proizvodnja elektroničke i električne opreme & 18,3 & 17,3 \\
\hline 16 & Proizvodnja motornih vozila & 4,4 & 3,4 \\
\hline 17 & Proizvodnja ostalih prijevoznih sredstava & 5,4 & 4,4 \\
\hline 18 & Proizvodnja namještaja & 7,6 & 6,6 \\
\hline 19 & Opskrba električnom energijom, plinom, parom i klimatizacija & 1,4 & 0,4 \\
\hline 20 & Distribucija vode i gospodarenje otpadom & $3,7,0$ & 0,7 \\
\hline 21 & Građevinarstvo & 3,7 & 2,7 \\
\hline 22 & Uslužne djelatnosti & 6,8 \\
\hline & Prosječno: & 3,5 \\
\cline { 2 - 5 } & Medijan: & & \\
\hline
\end{tabular}

Izvor: izračun autora 
T. GELO, D. KNEZ: Primjena input-output modela u analizi potrošnje vode kao inputa u gospodarstvu Hrvatske EKONOMSKI PREGLED, 72 (2) 272-307 (2021)

Tablica 6:

RAŠČLANJIVANJE MULTIPLIKATORA INDIREKTNE POTROŠNJE PO SEKTORIMA U 2004.

\begin{tabular}{|c|c|c|c|c|c|c|c|c|c|}
\hline & Sektor & 1 & 3 & 7 & 9 & 10 & 11 & 19 & 21 \\
\hline 1 & Primarni sektor & 0,236 & 0,093 & 0,066 & 0,000 & 0,012 & 0,004 & 0,000 & 0,125 \\
\hline 2 & Rudarstvo i vađenje & 0,009 & 0,003 & 0,051 & 0,001 & 0,008 & 0,026 & 0,006 & 0,335 \\
\hline 3 & $\begin{array}{l}\text { Proizvodnja prehrambenih i } \\
\text { duhanskih proizvoda }\end{array}$ & 0,339 & 0,150 & 0,153 & 0,001 & 0,014 & 0,009 & 0,001 & 0,276 \\
\hline 4 & $\begin{array}{l}\text { Proizvodnja tekstila, odjeće, kože i } \\
\text { srodnih proizvoda }\end{array}$ & 0,004 & 0,001 & 0,033 & 0,000 & 0,004 & 0,001 & 0,000 & 0,042 \\
\hline 5 & $\begin{array}{l}\text { Proizvodnja drva i proizvoda od drva } \\
\text { osim namještaja }\end{array}$ & 0,001 & 0,000 & 0,008 & 0,000 & 0,002 & 0,002 & 0,000 & 0,165 \\
\hline 6 & $\begin{array}{l}\text { Proizvodnja papira i proizvoda od } \\
\text { papira }\end{array}$ & 0,044 & 0,037 & 3,069 & 0,001 & 0,021 & 0,023 & 0,001 & 0,180 \\
\hline 7 & Tiskanje i srodne usluge & 0,001 & 0,000 & 0,014 & 0,000 & 0,000 & 0,000 & 0,000 & 0,009 \\
\hline 8 & $\begin{array}{l}\text { Proizvodnja koksa i rafiniranih } \\
\text { naftnih proizvoda }\end{array}$ & 0,637 & 0,115 & 1,601 & 0,013 & 0,160 & 0,305 & 0,124 & 9,512 \\
\hline 9 & $\begin{array}{l}\text { Proizvodnja kemijskih i } \\
\text { farmaceutskih proizvoda }\end{array}$ & 1,462 & 0,255 & 11,157 & 0,177 & 3,810 & 0,480 & 0,011 & 7,829 \\
\hline 10 & $\begin{array}{l}\text { Proizvodnja proizvoda od gume i } \\
\text { plastike }\end{array}$ & 0,017 & 0,009 & 0,210 & 0,001 & 0,060 & 0,004 & 0,000 & 0,144 \\
\hline 11 & $\begin{array}{l}\text { Proizvodnja ostalih nemetalnih } \\
\text { mineralnih proizvoda }\end{array}$ & 0,010 & 0,010 & 0,069 & 0,000 & 0,017 & 0,145 & 0,001 & 1,987 \\
\hline 12 & Proizvodnja metala & 0,003 & 0,002 & 0,075 & 0,000 & 0,030 & 0,015 & 0,000 & 0,777 \\
\hline 13 & $\begin{array}{l}\text { Proizvodi od metala, osim strojeva } \\
\text { i opreme }\end{array}$ & 0,001 & 0,001 & 0,010 & 0,000 & 0,002 & 0,001 & 0,000 & 0,115 \\
\hline 14 & Proizvodnja strojeva i uređaja & 0,001 & 0,000 & 0,003 & 0,000 & 0,000 & 0,000 & 0,000 & 0,012 \\
\hline 15 & $\begin{array}{l}\text { Proizvodnja elektroničke i električne } \\
\text { opreme }\end{array}$ & 0,000 & 0,000 & 0,003 & 0,000 & 0,000 & 0,000 & 0,000 & 0,024 \\
\hline 16 & Proizvodnja motornih vozila & 0,000 & 0,000 & 0,001 & 0,000 & 0,000 & 0,000 & 0,000 & 0,003 \\
\hline 17 & $\begin{array}{l}\text { Proizvodnja ostalih prijevoznih } \\
\text { sredstava }\end{array}$ & 0,001 & 0,000 & 0,013 & 0,000 & 0,000 & 0,000 & 0,000 & 0,008 \\
\hline 18 & Proizvodnja namještaja & 0,000 & 0,000 & 0,001 & 0,000 & 0,000 & 0,000 & 0,000 & 0,002 \\
\hline 19 & $\begin{array}{l}\text { Opskrba električnom energijom, } \\
\text { plinom, parom i klimatizacija }\end{array}$ & 0,604 & 0,367 & 6,567 & 0,055 & 0,782 & 2,087 & 0,216 & 11,757 \\
\hline 20 & $\begin{array}{l}\text { Distribucija vode i gospodarenje } \\
\text { otpadom }\end{array}$ & 0,017 & 0,007 & 0,172 & 0,000 & 0,008 & 0,013 & 0,001 & 1,081 \\
\hline 21 & Građevinarstvo & 0,001 & 0,001 & 0,014 & 0,000 & 0,001 & 0,003 & 0,000 & 0,192 \\
\hline \multirow[t]{2}{*}{22} & Uslužne djelatnosti & 0,198 & 0,069 & 1,930 & 0,006 & 0,121 & 0,123 & 0,011 & 2,469 \\
\hline & Multiplikator indirektne potrošnje & 3,6 & 1,1 & 25,2 & 0,3 & 5,1 & 3,2 & 0,4 & 37,0 \\
\hline
\end{tabular}

Izvor: izračun autora 
Tablica 7:

DIREKTNA NETO POTROŠNJA VODE I INTENZIVNOST POTROŠNJE VODE U 2010. GODINI PO SEKTORIMA

\begin{tabular}{|c|c|c|c|c|c|}
\hline & Sektor & $\begin{array}{c}\text { Direktna } \\
\text { potrošnja } \\
\text { vode } \\
{\left[000 \mathrm{~m}^{3}\right]}\end{array}$ & $\begin{array}{l}\text { Udio } \\
{[\%]}\end{array}$ & $\begin{array}{c}\text { Ukupni } \\
\text { output } \\
{[\text { mil. HRK] }}\end{array}$ & $\begin{array}{c}\text { Intenzivnost } \\
\text { direktne } \\
\text { potrošnje } \\
{\left[\mathrm{m}^{3} / \mathrm{mil} .\right.} \\
\text { HRK }]\end{array}$ \\
\hline 1 & Primarni sektor & 14.880 & $2,8 \%$ & 27.584 & 539 \\
\hline 2 & Rudarstvo i vađenje & 2.303 & $0,4 \%$ & 20.185 & 114 \\
\hline 3 & Proizvodnja prehrambenih i duhanskih proizvoda & 31.049 & $5,9 \%$ & 41.504 & 748 \\
\hline 4 & $\begin{array}{l}\text { Proizvodnja tekstila, odjeće, kože i srodnih } \\
\text { proizvoda }\end{array}$ & 3.645 & $0,7 \%$ & 13.642 & 267 \\
\hline 5 & $\begin{array}{l}\text { Proizvodnja drva i proizvoda od drva osim } \\
\text { namještaja }\end{array}$ & 484 & $0,1 \%$ & 3.773 & 128 \\
\hline 6 & Proizvodnja papira i proizvoda od papira & 4.603 & $0,9 \%$ & 6.212 & 741 \\
\hline 7 & Tiskanje i srodne usluge & 103 & $0,0 \%$ & 3.350 & 31 \\
\hline 8 & Proizvodnja koksa i rafiniranih naftnih proizvoda & 143.794 & $27,4 \%$ & 19.349 & 7.432 \\
\hline 9 & Proizvodnja kemijskih i farmaceutskih proizvoda & 92.903 & $17,7 \%$ & 23.816 & 3.901 \\
\hline 10 & Proizvodnja proizvoda od gume i plastike & 107 & $0,0 \%$ & 6.801 & 16 \\
\hline 11 & $\begin{array}{l}\text { Proizvodnja ostalih nemetalnih mineralnih } \\
\text { proizvoda }\end{array}$ & 10.169 & $1,9 \%$ & 7.269 & 1.399 \\
\hline 12 & Proizvodnja metala & 1.059 & $0,2 \%$ & 8.765 & 121 \\
\hline 13 & Proizvodi od metala, osim strojeva i opreme & 854 & $0,2 \%$ & 9.279 & 92 \\
\hline 14 & Proizvodnja strojeva i uređaja & 166 & $0,0 \%$ & 11.347 & 15 \\
\hline 15 & Proizvodnja elektroničke i električne opreme & 1.798 & $0,3 \%$ & 20.209 & 89 \\
\hline 16 & Proizvodnja motornih vozila & 135 & $0,0 \%$ & 6.376 & 21 \\
\hline 17 & Proizvodnja ostalih prijevoznih sredstava & 985 & $0,2 \%$ & 9.657 & 102 \\
\hline 18 & Proizvodnja namještaja & 332 & $0,1 \%$ & 7.025 & 47 \\
\hline 19 & $\begin{array}{l}\text { Opskrba električnom energijom, plinom, parom i } \\
\text { klimatizacija }\end{array}$ & 135.815 & $25,9 \%$ & 13.635 & 9.961 \\
\hline 20 & Distribucija vode i gospodarenje otpadom & 1.775 & $0,3 \%$ & 8.916 & 199 \\
\hline 21 & Građevinarstvo & 1.500 & $0,3 \%$ & 48.450 & 31 \\
\hline \multirow[t]{3}{*}{22} & Uslužne djelatnosti & 102.434 & $19,5 \%$ & 364.554 & 281 \\
\hline & Prosječno: & 25.040 & & 30.986 & 1.194 \\
\hline & Medijan: & 1.786 & & 10.502 & 125 \\
\hline
\end{tabular}

Izvor: izračun autora 
T. GELO, D. KNEZ: Primjena input-output modela u analizi potrošnje vode kao inputa u gospodarstvu Hrvatske EKONOMSKI PREGLED, 72 (2) 272-307 (2021)

Tablica 8:

\section{INTENZIVNOST INDIREKTNE I UKUPNE POTROŠNJE VODE PO SEKTORIMA U 2010.}

\begin{tabular}{|c|c|c|c|c|}
\hline & Sektor & $\begin{array}{c}\text { Intenzivnost } \\
\text { indirektne } \\
\text { potrošnje vode } \\
{\left[\mathrm{m}^{3} / \text { mil. HRK] }\right.}\end{array}$ & $\begin{array}{c}\text { Ukupna } \\
\text { intenzivnost } \\
\text { potrošnje vode } \\
{\left[\mathrm{m}^{3} / \text { mil. HRK }\right]}\end{array}$ & $\begin{array}{c}\text { Udio } \\
\text { indirektne } \\
\text { intenzivnosti } \\
\text { potrošnje vode }\end{array}$ \\
\hline 1 & Primarni sektor & 1.052 & 1.591 & $66 \%$ \\
\hline 2 & Rudarstvo i vađenje & 146 & 260 & $56 \%$ \\
\hline 3 & $\begin{array}{l}\text { Proizvodnja prehrambenih i duhanskih } \\
\text { proizvoda }\end{array}$ & 934 & 1.682 & $56 \%$ \\
\hline 4 & $\begin{array}{l}\text { Proizvodnja tekstila, odjeće, kože i srodnih } \\
\text { proizvoda }\end{array}$ & 651 & 918 & $71 \%$ \\
\hline 5 & $\begin{array}{l}\text { Proizvodnja drva i proizvoda od drva osim } \\
\text { namještaja }\end{array}$ & 669 & 798 & $84 \%$ \\
\hline 6 & Proizvodnja papira i proizvoda od papira & 622 & 1.363 & $46 \%$ \\
\hline 7 & Tiskanje i srodne usluge & 1.134 & 1.165 & $97 \%$ \\
\hline 8 & $\begin{array}{l}\text { Proizvodnja koksa i rafiniranih naftnih } \\
\text { proizvoda }\end{array}$ & 331 & 7.762 & $4 \%$ \\
\hline 9 & $\begin{array}{l}\text { Proizvodnja kemijskih i farmaceutskih } \\
\text { proizvoda }\end{array}$ & 845 & 4.746 & $18 \%$ \\
\hline 10 & Proizvodnja proizvoda od gume i plastike & 461 & 477 & $97 \%$ \\
\hline 11 & $\begin{array}{l}\text { Proizvodnja ostalih nemetalnih mineralnih } \\
\text { proizvoda }\end{array}$ & 864 & 2.263 & $38 \%$ \\
\hline 12 & Proizvodnja metala & 222 & 343 & $65 \%$ \\
\hline 13 & Proizvodi od metala, osim strojeva i opreme & 370 & 462 & $80 \%$ \\
\hline 14 & Proizvodnja strojeva i uređaja & 165 & 179 & $92 \%$ \\
\hline 15 & Proizvodnja elektroničke i električne opreme & 262 & 351 & $75 \%$ \\
\hline 16 & Proizvodnja motornih vozila & 90 & 111 & $81 \%$ \\
\hline 17 & Proizvodnja ostalih prijevoznih sredstava & 406 & 508 & $80 \%$ \\
\hline 18 & Proizvodnja namještaja & 385 & 432 & $89 \%$ \\
\hline 19 & $\begin{array}{l}\text { Opskrba električnom energijom, plinom, parom } \\
\text { i klimatizacija }\end{array}$ & 2.544 & 12.505 & $20 \%$ \\
\hline 20 & Distribucija vode i gospodarenje otpadom & 1.043 & 1.242 & $84 \%$ \\
\hline 21 & Građevinarstvo & 897 & 928 & $97 \%$ \\
\hline \multirow[t]{3}{*}{22} & Uslužne djelatnosti & 765 & 1.046 & $73 \%$ \\
\hline & Prosječno: & 675 & 1.870 & \\
\hline & Medijan: & 636 & 923 & \\
\hline
\end{tabular}

Izvor: obrada autora 
Tablica 9:

MEĐUSEKTORSKI VODNI TOKOVI ZA POJEDINE SEKTORE U 2010.

\begin{tabular}{|c|c|c|c|c|c|c|c|c|c|c|}
\hline & W & 1 & 3 & 7 & 9 & 10 & 11 & 19 & 20 & 21 \\
\hline 1 & Primarni sektor & 108 & 108 & 16 & 11 & 14 & 5 & 2 & 5 & 4 \\
\hline 2 & Rudarstvo i vađenje & 3 & 7 & 3 & 2 & 1 & 7 & 27 & 4 & 6 \\
\hline 3 & $\begin{array}{l}\text { Proizvodnja prehrambenih i } \\
\text { duhanskih proizvoda }\end{array}$ & 32 & 25 & 5 & 7 & 4 & 3 & 2 & 7 & 4 \\
\hline 4 & $\begin{array}{l}\text { Proizvodnja tekstila, odjeće, kože i } \\
\text { srodnih proizvoda }\end{array}$ & 0 & 0 & 1 & 0 & 1 & 2 & 0 & 1 & 1 \\
\hline 5 & $\begin{array}{l}\text { Proizvodnja drva i proizvoda od } \\
\text { drva osim namještaja }\end{array}$ & 0 & 1 & 1 & 0 & 1 & 1 & 0 & 0 & 1 \\
\hline 6 & $\begin{array}{l}\text { Proizvodnja papira i proizvoda od } \\
\text { papira }\end{array}$ & 3 & 17 & 70 & 13 & 7 & 10 & 2 & 10 & 5 \\
\hline 7 & Tiskanje i srodne usluge & 0 & 0 & 1 & 0 & 0 & 0 & 0 & 0 & 0 \\
\hline 8 & $\begin{array}{l}\text { Proizvodnja koksa i rafiniranih } \\
\text { naftnih proizvoda }\end{array}$ & 214 & 167 & 121 & 61 & 44 & 153 & 1.498 & 200 & 245 \\
\hline 9 & $\begin{array}{l}\text { Proizvodnja kemijskih i } \\
\text { farmaceutskih proizvoda }\end{array}$ & 403 & 226 & 427 & 491 & 224 & 189 & 26 & 299 & 77 \\
\hline 10 & $\begin{array}{l}\text { Proizvodnja proizvoda od gume i } \\
\text { plastike }\end{array}$ & 0 & 0 & 2 & 0 & 1 & 1 & 0 & 0 & 0 \\
\hline 11 & $\begin{array}{l}\text { Proizvodnja ostalih nemetalnih } \\
\text { mineralnih proizvoda }\end{array}$ & 4 & 12 & 5 & 4 & 3 & 45 & 3 & 21 & 115 \\
\hline 12 & Proizvodnja metala & 0 & 1 & 9 & 1 & 5 & 3 & 1 & 8 & 6 \\
\hline 13 & $\begin{array}{l}\text { Proizvodi od metala, osim strojeva } \\
\text { i opreme }\end{array}$ & 1 & 2 & 2 & 1 & 1 & 1 & 0 & 1 & 2 \\
\hline 14 & Proizvodnja strojeva i uređaja & 0 & 0 & 0 & 0 & 0 & 0 & 0 & 0 & 0 \\
\hline 15 & $\begin{array}{l}\text { Proizvodnja elektroničke i } \\
\text { električne opreme }\end{array}$ & 0 & 0 & 1 & 0 & 0 & 1 & 1 & 1 & 1 \\
\hline 16 & Proizvodnja motornih vozila & 0 & 0 & 0 & 0 & 0 & 0 & 0 & 0 & 0 \\
\hline 17 & $\begin{array}{l}\text { Proizvodnja ostalih prijevoznih } \\
\text { sredstava }\end{array}$ & 0 & 0 & 0 & 0 & 0 & 0 & 0 & 0 & 0 \\
\hline 18 & Proizvodnja namještaja & 0 & 0 & 0 & 0 & 0 & 0 & 0 & 0 & 0 \\
\hline 19 & $\begin{array}{l}\text { Opskrba električnom energijom, } \\
\text { plinom, parom i klimatizacija }\end{array}$ & 210 & 280 & 363 & 213 & 115 & 367 & 908 & 390 & 283 \\
\hline 20 & $\begin{array}{l}\text { Distribucija vode i gospodarenje } \\
\text { otpadom }\end{array}$ & 1 & 1 & 6 & 1 & 2 & 2 & 3 & 10 & 2 \\
\hline 21 & Građevinarstvo & 0 & 0 & 0 & 0 & 0 & 0 & 0 & 1 & 2 \\
\hline \multirow[t]{2}{*}{22} & Uslužne djelatnosti & 72 & 86 & 101 & 39 & 39 & 72 & 70 & 86 & 142 \\
\hline & Intenzitet indirektne potrošnje vode & 1.052 & 934 & 1.134 & 845 & 461 & 864 & 2.544 & 1.043 & 897 \\
\hline
\end{tabular}

Izvor: izračun autora 


\section{Tablica 10:}

\section{UKUPNI I INDIREKTNI MULTIPLIKATORI U 2010.}

\begin{tabular}{|c|c|c|c|}
\hline & Sektor & $\begin{array}{c}\text { Ukupni } \\
\text { multiplikator } \\
{[1]}\end{array}$ & $\begin{array}{c}\text { Indirektni } \\
\text { multiplikator } \\
{[1]}\end{array}$ \\
\hline 1 & Primarni sektor & 2,9 & 1,9 \\
\hline 2 & Rudarstvo i vađenje & 2,3 & 1,3 \\
\hline 3 & Proizvodnja prehrambenih i duhanskih proizvoda & 2,2 & 1,2 \\
\hline 4 & Proizvodnja tekstila, odjeće, kože i srodnih proizvoda & 3,4 & 2,4 \\
\hline 5 & Proizvodnja drva i proizvoda od drva osim namještaja & 6,2 & 5,2 \\
\hline 6 & Proizvodnja papira i proizvoda od papira & 1,8 & 0,8 \\
\hline 7 & Tiskanje i srodne usluge & 37,9 & 36,9 \\
\hline 8 & Proizvodnja koksa i rafiniranih naftnih proizvoda & 1,0 & 0,0 \\
\hline 9 & Proizvodnja kemijskih i farmaceutskih proizvoda & 1,2 & 0,2 \\
\hline 10 & Proizvodnja proizvoda od gume i plastike & 30,3 & 29,3 \\
\hline 11 & Proizvodnja ostalih nemetalnih mineralnih proizvoda & 1,6 & 0,6 \\
\hline 12 & Proizvodnja metala & 2,8 & 1,8 \\
\hline 13 & Proizvodi od metala, osim strojeva i opreme & 5,0 & 4,0 \\
\hline 14 & Proizvodnja strojeva i uređaja & 12,3 & 11,3 \\
\hline 15 & Proizvodnja elektroničke i električne opreme & 3,9 & 2,9 \\
\hline 16 & Proizvodnja motornih vozila & 5,2 & 4,2 \\
\hline 17 & Proizvodnja ostalih prijevoznih sredstava & 5,0 & 4,0 \\
\hline 18 & Proizvodnja namještaja & 9,1 & 8,1 \\
\hline 19 & Opskrba električnom energijom, plinom, parom i klimatizacija & 1,3 & 0,3 \\
\hline 20 & Distribucija vode i gospodarenje otpadom & 6,2 & 5,2 \\
\hline 21 & Građevinarstvo & 30,0 & 29,0 \\
\hline 22 & Uslužne djelatnosti & 3,7 & 2,7 \\
\hline & Prosječno: & 8,0 & 7,0 \\
\hline & Medijan: & 3,8 & 2,8 \\
\hline
\end{tabular}

Izvor: obrada autora 
Tablica 11:

\section{RAŠČLANJIVANJE MULTIPLIKATORA INDIREKTNE POTROŠNJE PO SEKTORIMA U 2010.}

\begin{tabular}{|c|c|c|c|c|c|c|c|c|c|}
\hline & Sektor & 1 & 3 & 7 & 9 & 10 & 11 & 19 & 21 \\
\hline 1 & Primarni sektor & 0,200 & 0,144 & 0,510 & 0,003 & 0,922 & 0,003 & 0,000 & 0,131 \\
\hline 2 & Rudarstvo i vađenje & 0,005 & 0,009 & 0,102 & 0,000 & 0,088 & 0,005 & 0,003 & 0,205 \\
\hline 3 & $\begin{array}{l}\text { Proizvodnja prehrambenih i } \\
\text { duhanskih proizvoda }\end{array}$ & 0,059 & 0,034 & 0,170 & 0,002 & 0,271 & 0,002 & 0,000 & 0,136 \\
\hline 4 & $\begin{array}{l}\text { Proizvodnja tekstila, odjeće, kože i } \\
\text { srodnih proizvoda }\end{array}$ & 0,000 & 0,000 & 0,033 & 0,000 & 0,037 & 0,001 & 0,000 & 0,020 \\
\hline 5 & $\begin{array}{l}\text { Proizvodnja drva i proizvoda od drva } \\
\text { osim namještaja }\end{array}$ & 0,000 & 0,001 & 0,023 & 0,000 & 0,032 & 0,001 & 0,000 & 0,023 \\
\hline 6 & $\begin{array}{l}\text { Proizvodnja papira i proizvoda od } \\
\text { papira }\end{array}$ & 0,006 & 0,023 & 2,286 & 0,003 & 0,448 & 0,007 & 0,000 & 0,148 \\
\hline 7 & Tiskanje i srodne usluge & 0,000 & 0,000 & 0,019 & 0,000 & 0,001 & 0,000 & 0,000 & 0,000 \\
\hline 8 & $\begin{array}{l}\text { Proizvodnja koksa i rafiniranih } \\
\text { naftnih proizvoda }\end{array}$ & 0,396 & 0,223 & 3,948 & 0,016 & 2,791 & 0,109 & 0,150 & 7,913 \\
\hline 9 & $\begin{array}{l}\text { Proizvodnja kemijskih i } \\
\text { farmaceutskih proizvoda }\end{array}$ & 0,748 & 0,301 & 13,873 & 0,126 & 14,228 & 0,135 & 0,003 & 2,497 \\
\hline 10 & $\begin{array}{l}\text { Proizvodnja proizvoda od gume i } \\
\text { plastike }\end{array}$ & 0,000 & 0,001 & 0,062 & 0,000 & 0,074 & 0,001 & 0,000 & 0,012 \\
\hline 11 & $\begin{array}{l}\text { Proizvodnja ostalih nemetalnih } \\
\text { mineralnih proizvoda }\end{array}$ & 0,008 & 0,016 & 0,151 & 0,001 & 0,187 & 0,032 & 0,000 & 3,715 \\
\hline 12 & Proizvodnja metala & 0,001 & 0,001 & 0,306 & 0,000 & 0,288 & 0,002 & 0,000 & 0,186 \\
\hline 13 & $\begin{array}{l}\text { Proizvodi od metala, osim strojeva } \\
\text { i opreme }\end{array}$ & 0,002 & 0,002 & 0,052 & 0,000 & 0,048 & 0,001 & 0,000 & 0,069 \\
\hline 14 & Proizvodnja strojeva i uređaja & 0,000 & 0,000 & 0,004 & 0,000 & 0,003 & 0,000 & 0,000 & 0,006 \\
\hline 15 & $\begin{array}{l}\text { Proizvodnja elektroničke i električne } \\
\text { opreme }\end{array}$ & 0,000 & 0,000 & 0,026 & 0,000 & 0,014 & 0,001 & 0,000 & 0,047 \\
\hline 16 & Proizvodnja motornih vozila & 0,000 & 0,000 & 0,001 & 0,000 & 0,001 & 0,000 & 0,000 & 0,003 \\
\hline 17 & $\begin{array}{l}\text { Proizvodnja ostalih prijevoznih } \\
\text { sredstava }\end{array}$ & 0,000 & 0,000 & 0,003 & 0,000 & 0,003 & 0,000 & 0,000 & 0,004 \\
\hline 18 & Proizvodnja namještaja & 0,000 & 0,000 & 0,006 & 0,000 & 0,004 & 0,000 & 0,000 & 0,005 \\
\hline 19 & $\begin{array}{l}\text { Opskrba električnom energijom, } \\
\text { plinom, parom i klimatizacija }\end{array}$ & 0,390 & 0,375 & 11,792 & 0,055 & 7,287 & 0,262 & 0,091 & 9,135 \\
\hline 20 & $\begin{array}{l}\text { Distribucija vode i gospodarenje } \\
\text { otpadom }\end{array}$ & 0,001 & 0,002 & 0,211 & 0,000 & 0,141 & 0,001 & 0,000 & 0,058 \\
\hline 21 & Građevinarstvo & 0,000 & 0,000 & 0,006 & 0,000 & 0,004 & 0,000 & 0,000 & 0,061 \\
\hline \multirow[t]{2}{*}{22} & Uslužne djelatnosti & 0,133 & 0,115 & 3,290 & 0,010 & 2,455 & 0,052 & 0,007 & 4,585 \\
\hline & Multiplikator indirektne potrošnje & 1,9 & 1,2 & 36,9 & 0,2 & 29,3 & 0,6 & 0,3 & 29,0 \\
\hline
\end{tabular}

Izvor: obrada autora 


\title{
THE APPLICATION OF THE INPUT-OUTPUT MODEL IN THE WATER CONSUMPTION ANALYSIS AS AN INPUT IN THE CROATIAN ECONOMY
}

\author{
Summary
}

The paper analyses the application of the input-output model in water consumption. Water as a limited resource and input in the Croatian economy is researched through intersectoral relationships of sectors in the national economy breakdown, based on two hybrid input-output models, for 2004 and 2010. The change in time relationship between the economy and water resources is also analysed. Sectors are mutually connected. Therefore, each change in aggregate consumption will affect the water consumption distribution in each sector. This fact results in the importance of analysing intermediary relationships at the level of the national economy, and consequently, the impact of the national economy on the available water resources.

The paper uses the hybrid input-output model for water consumption, created for 2004 and 2010, based on the available publications of the Croatian Bureau of Statistics and the Croatian Environmental Protection Agency. The base publications for creating the model are supply and use tables, from which symmetrical input-output tables for 2004 and 2010 were extrapolated, and the data on water distribution in 2004 and 2010. In the hybrid model, the entire Croatian economy was broken down into 22 sectors. Each sector was created by consolidating various activities from the National Classification of Activities (NKD) in 2002 and 2007. The model determines the intensities of direct and indirect water consumption, and consequently, the total water consumption intensity, and direct and total consumption multipliers. The model results for the stated years indicate that there are only several industrial sectors in the Croatian economy which have a dominant direct impact on water resources (electricity generation, Coke and refined petroleum products and Chemicals and chemical products). A decrease in the impact on water resources in Croatia can be achieved by decreasing the consumption intensity of water resources in the observed sectors. In the application of the obtained results, the limitations of the hybrid input-output model, which is static, and the lack of data on water consumption in all sectors should be taken into consideration.

Key words: hybrid model, input-output analysis, water intensity, sectors, economy 